\title{
Deposit Insurance Schemes and Bank Stability in Europe: How Much Does Design Matter?
}

\author{
Laura Chiaramonte*, Claudia Girardone ${ }^{\circ}$ Milena Migliavacca*, Federica Poli*
}

\begin{abstract}
$\underline{\text { Abstract }}$
Using a detailed set of Deposit Insurance Schemes (DIS) features for 27 EU countries, we assess the impact of national deposit insurance features on bank stability and investigate the existence of nonlinearities in the relationship between coverage and bank stability both in crisis and normal times. Our results suggest that more protective DIS do not necessarily lead to greater bank risk. However, during the crisis some features that generate moral hazard incentives can decrease bank stability. We find an inverse U-shaped relation with bank stability decreasing at high levels of coverage during the crisis period. However, our evidence also suggests that the introduction of temporary measures like blanket guarantees are crucial to avoid panic among depositors and restore stability. Finally, our results seem to imply that the stabilizing effect of deposit insurance can be different along the economic cycle, so regulators should consider that to be able to achieve an optimal DIS that minimizes moral hazard incentives a 'dynamic' approach may be necessary.
\end{abstract}

Keywords: Deposit Insurance; Bank Stability; European Banking; Financial Crisis.

JEL Classification: G21; G01.

\footnotetext{
* Department of Economics and Business Administration, Faculty of Economics, Università Cattolica del Sacro Cuore, Largo Gemelli 1, Milan, 20123, Italy.

${ }^{\circ}$ Department of Accounting Finance and Management, University of Essex, Wivenhoe Park, Colchester CO4 3SQ, UK.

E-mail addresses: laura.chiaramonte@unicatt.it (L. Chiaramonte); cgirard@essex.ac.uk (C. Girardone); milena.migliavacca@unicatt.it (M. Migliavacca); federica.poli@unicatt.it (F. Poli).
} 


\section{Introduction}

During the last few decades many developed and emerging countries introduced and/or revised their Deposit Insurance Schemes (DIS) to make safety nets more effective, forestall bank runs and reduce public costs associated with bank failures (Demirgüç-Kunt et al., 2015). In the European Union (EU), a weakness of the original regulatory framework was the lack of a homogeneous approach that was leaving room to potential distortions, which could undermine national DIS effectiveness to curb bank risk, particularly in the long-run. Recent regulatory adjustments have resulted in a sizeable increase in the maximum amount of coverage per depositor from $€ 20,000$ to $€ 100,000$ in 2009 . However, deposit insurance provisions include a relatively wide range of features in addition to coverage, that can have an incremental effect on moral hazard incentives. These include co-insurance and powers to intervene a bank, as well as the way the funding and administration of DIS are organised. In relation to this latter, in 2014 several modifications of national DIS have also been introduced. ${ }^{1}$ Despite the steps towards a more harmonized deposit insurance provision in Europe, a common system for deposit protection that would complete the Banking Union has not yet been established.

The DIS features are generally expected to enhance depositors' confidence and minimize banks' moral hazard conduct; however too generous or lax schemes may also promote bank risktaking and make financial systems vulnerable to crises (Demirgüç-Kunt and Detriagiache, 2002; Barth et al., 2013; International Association of Deposit Insurers - IADI, 2013a, 2013b, 2014). The topic is well researched but theoretical and empirical findings are mixed and in some cases even

\footnotetext{
${ }^{1}$ For fifteen years the design of DIS was left to national discretion and there was only a minimum harmonisation. The European deposit protection schemes were regulated by Directive 1994/19/EC that remained substantially unchanged until the outburst of the global financial crisis. The EU enacted two Directives in 2009 and 2014 to amend the existing European DIS.
} 
contradictory, thus it remains open to more investigation. In addition, there are only a handful of studies focusing on the EU case. Gropp and Vesala (2004), for example, use data from the 1990s and find that the presence of deposit insurance increases banking sector stability. Anginer et al. (2014) find that publicly traded banks operating in 96 countries are more stable in presence of more protective DIS, especially during the 2007-2008 financial crisis. In contrast, other studies show that the relationship with stability is not always straightforward. Barth et al. (2004) find a positive association between banking crises and levels of deposit insurance while Demirgüç-Kunt and Detragiache (2002), Laeven (2002), Demirgüç-Kunt and Huizinga (1999, 2004) and Forssbaeck (2011) find that deposit insurance represents an incentive for bank risk-taking. Similarly, Lambert et al. (2017) offer evidence of the unintended effects of the increase in deposit insurance in the US in 2008, as banks that significantly increased the amount of insured deposits after the enactment of the new rules became overall riskier.

This paper provides several contributions to the extant literature. First, to the best of our knowledge, it is the first to focus on the European case in the 2000s, based on a sample of banks headquartered in the $27 \mathrm{EU}$ member states ${ }^{2}$ over a relatively long period that includes the financial crises. Most existing empirical studies either concentrate on the US case or, if they extend the analysis to other countries, including Europe, they examine only selected features of the deposit insurance arrangements. Our study relies on a very detailed set of DIS features calibrated according to the Bank Regulation and Supervision (BRS) Surveys carried out by the World Bank (2003, 2007 and 2012) and the European Commission reports (2004, 2010 and 2011). In particular, it includes: i) the degree of deposit coverage provided by national DIS; ii) the funding of national DIS and their administration; and finally, iii) the power of intervention of DIS on banks and their management.

\footnotetext{
${ }^{2}$ We consider the EU composition at the beginning of 2013 (the last year of our analysis). As Croatia joined the EU on 1 July 2013, we limit the data sample to twenty seven member states (EU27).
} 
Second, this study not only assesses the relationship between deposit insurance coverage over GDP per capita and bank stability and possible non-linearities, but also focuses on the relationship between DIS features and stability in the global financial and sovereign debt crises compared to the pre-crisis period. As far as we know, this has not been done before for EU countries. We hypothesize that the relationship between DIS features and moral hazard incentives may differ in normal vs turbulent times, and that too generous schemes, particularly excessively high insurance coverage, can induce greater risk-taking behaviour and make financial systems more fragile.

Third, our study examines whether the effect of a selection of DIS features on bank stability varies by banks' business model, size, and degree of dependency on deposit funding. It also investigates the effects of DIS under different 'operating environments' (IADI, 2014) taking into account the health of the EU economies (i.e. countries less affected by the financial and sovereign crises), the orientation of the financial systems (bank- vs market-oriented), and the power of the supervisory authority. In terms of policy implications, our analysis allows to retrospectively assess the goodness of regulatory novelties introduced by the 2014/49/EC Directive (i.e. mandatory ex-ante premia and risk-adjusted premia) and contributes to the debate related to the efficacy of the design of DIS in safeguarding the stability of the banking sector (Financial Stability Board - FSB, 2012; IADI, 2014). It also lends itself well to useful considerations in light of 1) the need, formulated in the EU Directive 2014/49, to assess the adequacy of the European DIS and its impact on the different business models; and 2) the build-up of the third pillar of the European Banking Union that is still missing, the EDIS (European Deposit insurance Scheme).

Our main findings are broadly consistent with those of Angkinand and Wihlborg (2010), Anginer et al. (2014) and Liu et al. (2016) and extend them to include evidence of non-linearities between coverage and stability for a detailed and large EU sample using recent data. Specifically, our results reveal an inverse U-shape pattern where bank risk increases at high levels of coverage. The identified quadratic relationship allows us to calculate the turning point and estimate that during the crisis the 
level of coverage at which bank stability start diminishing is 3.6 times the GDP per capita. We find evidence that DIS without co-insurance are more stable both in tranquil and financially turbulent times. In addition, the introduction of temporary measures, like blanket guarantees, appear crucial to avoid panic among depositors. During the crisis some features that generate moral hazard incentives can decrease bank stability, such as for countries characterized by the absence of risk-adjusted premia. It also indicates that often it is not the single feature but the interaction among different ones to affect significantly bank stability. Finally, we show that the composite design of a DIS exerts a different impact on bank stability depending on the bank types and business models as well as on the characteristics of the operating environment.

The remainder of the paper is organized as follows. Section 2 reviews the main literature. Section 3 describes the data sample and the methods used for the empirical analysis. Section 4 discusses the main results. Section 5 presents various robustness tests. Section 6 concludes and discusses policy implications.

\section{Selected literature and research hypotheses}

Over the past forty years, seminal theoretical studies have been carried out that highlight the benefits of deposit insurance (Diamond and Dybvig, 1983; Kane, 1995). Nonetheless, this provision can also provide banks incentives to increase risk exposure in search for higher profits, as long as the deposit insurer will cover a large part of banks' debts in case of default (Merton, 1978; Acharya, 2009). Typically, DIS have been associated with the presence of a coverage and its optimal level (Dreyfus et al., 1994; Cordella and Yeyati, 2002), but recent years have seen increasing evidence that other DIS features are equally important in triggering risk incentives and sometimes it is their joint effect to matter the most. This suggests that to mitigate moral hazard a DIS should include appropriate design features. Examples include: differential or risk-adjusted premium systems, limits on the amounts insured, exclusion of certain categories of depositors from coverage, and mechanisms for 
the minimization of the risk of loss through timely intervention and resolution of troubled and failed institutions by the deposit insurer or other participants in the financial safety net (Pennacchi, 1987, 2006; Grossman, 1992). Other important characteristics of DIS are the nature of the deposit insurer (public vs private) and the source of funding (Calomiris, 1990; Kane, 1991; Morrison and White, 2011; Calomiris and Jaremski, 2016). This implies that to be effective, DIS should be designed taking into account the extent to which the interaction of different features pertaining the amount of the deposit insurance, the funding, the administration and power of intervention of the deposit insurer can magnify bank moral hazard.

In light of the above, we formulate the following research hypotheses:

H1. The generosity of the deposit insurance coverage decreases bank stability.

H2. Banks become more unstable when the funding and administration arrangements of national deposit insurance schemes generate moral hazard incentives.

H3. Bank stability is lower when deposit insurers do not exercise disciplinary power on banks.

The first hypothesis $H 1$ suggests that a generous DIS may lead to higher moral hazard (Dermiguc-Kunt and Levine, 2000) that ultimately decreases bank stability. ${ }^{3}$ We also conjecture that funding and administration practices and the presence of power of intervention can impact bank stability. We expect these relationships to be more pronounced in periods of crisis, especially relative to $H 2$ and $H 3$.

\footnotetext{
${ }^{3}$ We associate high generosity of DIS with a situation that could promote risk-taking. For example, in Garcia (1999) excessively high coverage contributed to the US Savings \& Loans banking crisis in the 1980s. Similarly, Demirguc-Kunt and Levine (2000) do not clarify generosity in quantitative terms but use "excessive coverage" as the meaning of generosity.
} 
The empirical literature on the effects of explicit deposit insurance design on bank moral hazard provides mixed results and is mostly focused on selected features of the deposit insurance system. Early studies in the US tend to find no significant effects (Wheelock and Wilson, 1995; Karels and McClatchey, 1999). While Gropp and Vesala (2004)'s empirical investigation on European countries over the 1990s, finds that the presence of deposit insurance can reduce moral hazard. However, most recent studies that employ large international samples find opposite results.

Demirgüç-Kunt and Detragiache (2002), Demirgüç-Kunt and Kane (2002), Laeven (2002), Barth et al. (2004), Demirgüç-Kunt and Huizinga (2004) and Forssbaeck (2011) provide evidence that deposit insurance exerts an adverse impact on banks' stability and failures. Similar conclusions emerge from the analysis of Ioannidou and Penas (2010) for Bolivia. Whereas Angkinand and Wihlborg (2010) find evidence of a U-shaped relationship between deposit coverage and bank risktaking in Eastern European and Asian emerging countries. Lambert et al. (2017) in contrast, report an increase in US bank risk after the enactment of the US Emergency Economic Stabilization Act in October 2008, which augmented the deposit insurance coverage from $\$ 100,000$ to $\$ 250,000$ per depositor and bank.

Some empirical works differentiate the effects of DIS on moral hazard distinguishing between crisis and non-crisis years. In a large cross-country study, for example, Anginer et al. (2014) offer evidence of a stabilizing effect of deposit insurance schemes when the probability of a bank's failure is particularly high especially over 2007-2009. Similarly, Liu et al. (2016) find not only that banks in countries with explicit deposit insurance systems have higher credit default swaps (CDSs) spreads, but also that full coverage exerts a stabilizing effect on bank risk during the financial crisis period.

Normally, in case of substantial bank distress and risk of systemic crisis in the financial sector, policy-makers rely on temporary blanket guarantees on bank liabilities to prevent or end bank runs. The effectiveness of such interventions is strictly dependent on their credibility, while their implementation may give rise to moral hazard concerns in addition to fiscal costs. Laeven and 
Valencia (2012) analyse a large international sample of episodes of banking crises and find that blanket guarantees are successful in reducing liquidity pressures on banks arising from deposit withdrawals from residents, while the same effect is less pronounced for non-residents. Gropp et al. $(2010 ; 2013)$ document that bailouts and guarantees undermine market participants' monitoring incentives and increase bank moral hazard. Nys et al. (2015) provide evidence for a sample of commercial Indonesian banks that the switch from a blanket guarantee regime to a formal deposit insurance with limited coverage increases market discipline; such an effect, however, being tempered by the presence of political connections.

Only a handful of empirical works have investigated the relationships between several features of the insurance deposit schemes and bank stability. Demirgüç-Kunt and Detragiache (2002) use an international sample over 1980-1997 and show that the adverse impact of deposit insurance on bank stability is stronger the more extensive is the coverage offered to depositors and where the scheme is run by the government rather than by the private sector.

Hovakimian et al. (2003) employ an international sample and find that the introduction of explicit deposit insurance exacerbates bank risk but this phenomenon is mitigated by the contextual presence of loss-control mechanisms such as: risk-adjusted deposit insurance premiums, co-insurance and coverage limits. Cull et al. (2005) use an international dataset capturing a variety of deposit insurance features across countries, including coverage, premium structure, etc. and synthesize available information by means of principal component indices. Their empirical evidence is consistent with the likelihood that generous government-funded deposit insurance might have a negative impact on the long-run growth and stability of bank intermediation, except in countries where the rule of law is well established and bank supervisors are granted sufficient discretion and independence from legal reprisals. Insurance premium requirements on member banks, even when risk-adjusted, are instead found to have little effect in restraining banks' risk-taking behaviour. Liu et al. (2016) study the linkage between bank risk and deposit insurance, using data on bank CDSs to 
measure bank risk for 161 global banks operating in 23 countries over 2000-2011, and show that deposit insurance design features such as risk-adjusted premiums and co-insurance tend to lower banks' credit risk. The authors find that government-established systems contribute to lessen the adverse impact on bank risk exerted by deposit insurance.

\section{Data sample and methodology}

\subsection{Data sources and sample}

This study focuses on commercial, cooperative and savings banks operating in 27 EU member states. Our sample includes 4,187 banks and covers the period 2003-2013. The countries with the largest proportion of commercial banks are France, Germany and the UK; whereas cooperative and savings banks are more common in Austria, Germany and Italy. ${ }^{4}$

The deposit insurance design features are collected from the cross-country database on bank regulation and supervision compiled by the World Bank (2003, 2007, and 2012) and the European Commission reports (2004, 2010, and 2011). Bank-specific variables are extracted from the BankScope database. Other relevant variables are collected from the EU Banking Structures Reports available from the ECB website (namely, the banking sector concentration ratio), Eurostat and the World Bank Financial Development Database (for the macroeconomic variables, such as GDP growth and real GDP per capita). We use annual consolidated bank statements and, when not available, unconsolidated statements. This allows us to consider entities, such as large European banking groups, whose components, although individually important (in an unconsolidated form), are managed according to a unitary and complementary logic at group level.

\footnotetext{
${ }^{4}$ Interestingly, Austria, Germany and Italy have also the largest number of listed banks (94\% of banks included in our sample are unlisted). See Table 5 for the breakdown of observations by bank business model.
} 


\subsection{Variables description}

To test the hypotheses formulated above, in our empirical models (detailed in Section 3.3) we employ as dependent variable our chosen measure of bank stability (Section 3.2.1) and as target variables, the DIS features (described in Section 3.2.2). We also control for selected bank- and country-specific characteristics (Section 3.2.3). Table 1 provides brief definitions of all variables . Correlation coefficients and their significance levels can be found in Table A.1 in the Appendix.

[Insert Table 1 about here]

\subsubsection{Measuring bank stability}

The dependent variable in our main models is the Z-score, a measure of bank stability that indicates the distance from insolvency (see e.g. Beck and Laeven, 2006). The Z-score is widely used and calculated as the sum of equity to total assets (ETA) and return on average assets (ROAA) scaled by the three-year standard deviation of ROAA. It combines accounting measures of profitability, leverage and volatility and reflects the number of standard deviations by which returns would have to fall from the mean to wipe out bank equity. ${ }^{5}$ Higher Z-score values indicate a lower probability of insolvency risk and thus greater bank ability to face losses. Since the Z-score is highly skewed, we

\footnotetext{
5 We use this method of calculating the distance-to-default using accounting-based rather than market-based risk measures because we include a relatively large number of (unlisted) mutual banks in our sample as, for example, in Hesse and Cihák (2007); Garcia-Marco and Roblez-Fernandez (2008); Beck et al. (2009); Laeven and Levine (2009); Chiaramonte et al. (2015a,b; 2016). De Nicolo (2000) and Stiroh, (2004a and 2004b) use the Z-score as a measure of riskadjusted performance. There are different ways of calculating the Z-score (Boyd et al. 2006; Yeyati and Micco, 2007; Delis et al. 2012) and indeed of financial stability risk, as shown e.g. in Aikman et al. (2018) that use a range of indicators to produce composite measures of stability.
} 
use its natural logarithm (Laeven and Levine, 2009; Liu et al., 2016). To mitigate the effects of outliers, Z-score is winsorized at the $1 \%$ of each tail.

Table 2 presents the descriptive statistics of the decomposition of the Z-score by year over 2003-2013. During the most acute phase of the crisis its average values dropped considerably, reaching its lowest value (4.176) in 2009 compared to 4.230 in the previous period. This is due to both the decline in operating profit and the increase in the volatility of returns ( $\sigma$ ROAA). In 20112013, the average Z-score rose from 4.577 to 4.791 , thus reaching values higher than the pre-crisis years. One possible explanation is the significant deleveraging process that many banks have embarked on since the global crisis, and that resulted in greater total equity as a proportion of total assets.

[Insert Table 2 about here]

Using the Z-score as a measure of distance to default, entails the possibility of the results being driven by one of its components. Hence, we test our hypotheses using as dependent variables ETA, ROAA and the standard deviation of ROAA. For additional robustness, we also replace the Z-score with the Tier 1 capital ratio (TIER1 RATIO) and a proxy of credit quality (loan loss reserves to gross loans, LLR_GL).

\subsubsection{Deposit insurance design features: coverage, funding \& administration, and intervention}

We consider three sets of DIS design features that reflect the nature of national DIS design, namely: the degree of deposit coverage provided by national DIS; the bank contribution to the DIS and its administration; and the power of intervention of the DIS on the banks and their management.

To verify $H 1$, on the effect of generosity of deposit insurance on bank stability, we use three measures: (1) the coverage ratio (COV_RATIO), that is equal to the amount of deposits refunded in 
the event of bank failure scaled by the national GDP per capita, and its square (COV_RATIO2); ${ }^{6}(2)$ an aggregate explanatory variable COVERAGE, that corresponds to the sum of the dummy variables HIGH_COV and NO_COINS (see Table 1); and (3) the effect of blanket guarantees (BLANKET). We hypothesize a negative relationship between the above measures of generosity and the Z-score because too generous DIS could raise bank risk both in normal and bad times.

Panel A of Table 3 reports the national levels of deposit insurance coverage (in euros and scaled by real GDP per capita); the dummies HIGH_COV and NO_COINS in 2003, 2008, and 2013. Overall, it is possible to see a substantial increase, albeit unevenly spread over time and across countries. The harmonization of the coverage levels to $€ 100,000$ amplifies the national disparities in terms of generosity of the DIS. The dummy HIGH_COV does not change over time as the deposit insurance coverages are lower than the annual mean values only for four countries: Denmark, Germany, Luxembourg, and Sweden. ${ }^{7}$ Additionally, co-insurance (NO_COINS), rather common prior to the crisis, was largely abandoned over 2008-2009.

[Insert Table 3 about here]

The second independent variable, FUNDING \& ADMIN, is obtained summing up the following four features: source of funding (GOV_FUND), the timing of bank contribution to the insurance fund (NO_EXANTE), the differential premium system in force (NO_RISKADJ), and the

\footnotetext{
${ }^{6}$ Since the coverage ratios are highly skewed, we use their natural logarithm.

${ }^{7}$ Some EU countries (i.e., Germany and Austria) set up mutual and voluntary schemes advertised as offering unlimited depositors' guarantees. Despite this, for example, the German government declared political unlimited deposit guarantees. For more details, see European Commission (2010).
} 
administration of the DIS (GOV_ADMIN). ${ }^{8}$ Based on our second hypothesis, $H 2$, we expect negative signs, because banks may be more prone to take risks if national DIS generate moral hazard incentives, i.e. if premia are not risk-adjusted, the timing of bank contribution is not set clearly, or the administration and funding of the DIS is public. Table 3, panel B, shows that for most EU27 DIS, the funds are entirely provided by banks and only a handful of countries (namely, Austria, Italy, Luxembourg, Slovenia, and United Kingdom) adopt ex-post premia. Contributions are usually not risk-adjusted while the governance of the national DIS rests on governments, sometimes jointly with banks.

To test for $H 3$, the third aggregate independent variable, INTERVENTION, encapsulates the ability of the deposit insurer itself to discipline and act against banks. It includes: the lack of power of intervention on bank members (NO_INTERV); the inability to cancel or revoke deposit insurance for any participating bank (NO_CANCEL); and the inability to take legal actions against banks' directors/officials involved in bank failures (NO_LEGALPWR). ${ }^{9}$ If deposit insurers do not exercise any disciplinary power over banks, bank stability should be weaker. Hence, a negative sign is expected. Table 3, panel C, reveals that only a handful of EU27 countries allow DIS interventions on banks. It also shows a widespread absence of deposit insurers' 'sole' power to cancel the provision for any banks and to take legal actions, as these powers are typically shared with supervisory and judicial authorities.

\subsubsection{Control variables}

\footnotetext{
${ }^{8}$ For the case of Germany the variable GOV_ADMIN takes the value 1 for savings and pure public banks and 0 for private commercial and cooperative banks.

${ }^{9}$ Surveyed banks were also asked whether the national insurance authority has ever actually taken legal actions against bank directors or officials. We omitted this last variable from the analysis, since there is no way to ascertain whether legal actions were not taken either because never needed or due to laxity on the part of the authority.
} 
In our empirical specifications we control for bank- (size, capitalisation, reliance towards deposits, efficiency, income diversification and credit risk) and country-specific characteristics (bank industry concentration, economic growth and institutional quality, as proxied by the GDP per capita, similarly to Angkinand and Wihlborg, 2010) that may affect bank stability. Table 1 reports their definitions and expected signs. Typically, the level of bank capitalisation, efficiency, income diversification and asset quality as well as the macro variables have been found to be positively related to bank stability in the relevant literature (e.g., see Stiroh, 2004a; Angkinand and Wihlborg, 2010; Chiaramonte et al., 2015b; Anginer et al., 2014). Whereas, for other variable like size, business models and banking market conditions, the relationships are far from straightforward (e.g. Fiordelisi and Mare, 2014; Mare, 2015; Becchetti et al., 2016).

To mitigate the effect of outliers, all control variables are winsorized in the outside $1 \%$ of each tail. Finally, we include a dummy controlling for financial and sovereign crises (CRISIS), which takes the value of 1 for the years 2008-2013, and 0 otherwise. ${ }^{10}$ Summary statistics and tests of the differences in means between the pre-crisis and crisis period are reported in Table 4.

[Insert Table 4 about here]

The average values of CIR, DIV, and HHI remained virtually unchanged for our sample of banks over the period under investigation (where statistically significant differences are small). Bank SIZE appear to have increased significantly on average in the crisis years, possibly driven by the process of consolidation. Equally, the deterioration of the quality of banks' credit portfolios after the

\footnotetext{
${ }^{10}$ We identified an alternative timeline of the financial crisis starting in the third quarter of 2007 (Bank for International Settlements - BIS, 2009); using quarterly data collected from BankScope database, we ensured the robustness of our empirical results to this different specification.
} 
outbreak of the crisis led to a substantial increase in the LLR_GL variable. The average value of GDP_PC also rose significantly during the crisis years, especially in countries less affected by the financial and sovereign crises.

In contrast, DEP_TA and $\triangle$ GDP declined on average in the crisis years, possibly as a result of lower depositor confidence on the stability of the banking sector and the contraction in the main determinants of demand, respectively. We also observed a reduction in bank leverage (i.e. higher values of ETA). This is largely explained by both the deleveraging process and recapitalisation of many European banks in the wake of the financial crisis. Focusing on the difference in means between the two sub-periods, we find that with only one exception, for our control variables it is possible to identify a statistically significant change during the crisis.

Table A.1 in the Appendix reports the correlation matrix of all DIS features used in the empirical analyses. Although most pairwise correlation coefficients are statistically significant the correlation magnitudes are usually relatively low.

\subsection{Empirical models}

Our methodology is composed of two steps. The first is described in our baseline model (Eq. 1) and explores possible non-linearities in the relationship between coverage and bank stability $(H 1)$; as well the relationship between the latter and other deposit insurance features, namely FUNDING \& ADMIN (H2) and INTERVENTION (H3) in their additive terms.

For the empirical analysis we employ the following fixed-effects panel data regression model:

$$
\begin{aligned}
& Z-\text { score }_{i j, t}=\alpha_{i}+\beta_{1} \text { COV_RATIO }_{j, t-1} * \text { pre }- \text { crisis }+\beta_{2} \operatorname{COV}_{-} \mathrm{RATIO}_{j, t-1} * \text { pre }- \text { crisis }+ \\
& \beta_{3} \text { COV_RATIO }_{j, t-1} * \text { crisis }+\beta_{4} \text { COV_RATIO2 }_{j, t-1} * \text { crisis }+\beta_{5} \text { FUNDING \& ADMIN }_{j, t-1} * \text { pre }- \text { crisis }+ \\
& \beta_{6} \text { FUNDING \& ADMIN }_{j, t-1} * \text { crisis }+\beta_{7} \text { INTERVENTION }_{j, t-1} * \text { pre }- \text { crisis }+\beta_{8} \text { INTERVENTION }_{j, t-1} * \text { crisis }_{+}+ \\
& \beta_{9} \text { CRISIS }+\beta_{10} \text { BankControls }_{i j, t-1}+\beta_{11} \text { CountryControls }_{j, t-1}+\varepsilon_{i j, t}
\end{aligned}
$$


where $Z$-score $i j, t$ is the main stability measure of bank $i$ in country $j$ at time $t$. The explanatory variables $C O V \_R A T I O_{j, t-1}$ and $C O V \_R A T I O 2_{j, t-1}$ are, respectively, the natural logarithm of the deposit insurance coverage scaled by the real GDP per capita and its square in country $j$ at time $t$ - 1 . In addition, we include the remaining deposit insurance scheme design features in their additive form (FUNDING \& ADMIN $_{j, t-1}$ and INTERVENTION $\left.{ }_{j, t-1}\right)$. It is to note that the variable co-insurance (NO_COINS) is not included in this model due to collinearity.

Following Anginer et al. (2014)'s empirical strategy, the DIS design features are interacted with the pre-crisis (2003-2007) and crisis years (2008-2013) dummies, respectively. Since we also include the crisis dummy (CRISIS) in our model, the coefficients on the interaction terms should be interpreted as the differences in distance-to-default of banks which are operating in a given DIS setting and those without. We also include bank- (BankControls $\left.s_{i, t,-1}\right)$ and country-specific characteristics $\left(\right.$ CountryControls $\left._{i, t,-1}\right)$ that are expected to significantly affect banks' stability. All explanatory variables are lagged by one year to alleviate any reverse causality problem. The standard errors are clustered at the bank-level. Finally, $\alpha_{i}$ is the bank fixed-effects and $\varepsilon_{i j, t}$ is the error term. To strengthen the validity of our findings we run a set of further analyses and robustness checks in Sections 4 and 5.

The second step involves identifying the effect of the aggregate design features of EU27 deposit insurance schemes on banks' stability employing the following fixed-effects panel data regression:

$$
\begin{aligned}
& Z-\text { score }_{i j, t}=\alpha_{i}+\beta_{1} \text { DesignFeatures }_{j, t-1} * \text { pre }_{\text {- }} \text { crisis }+\beta_{2} \text { DesignFeatures }_{j, t-1} * \text { crisis } \\
& +\beta_{3} \text { CRISIS }+\beta_{4} \text { BankControls }_{i j, t-1}+\beta_{5} \text { CountryControls }_{j, t-1}+\varepsilon_{i j, t}
\end{aligned}
$$


where the dummies DesignFeatures ${ }_{j, t-1}$, representing the single DIS features or the three aggregate dummies COVERAGE, FUNDING \& ADMIN and INTERVENTION in country $j$ at time $t$-1, are interacted with the pre-crisis and crisis years dummies. We further control for the set of bank and country characteristics used in the baseline model.

\section{Main Results}

\subsection{The baseline model}

Table 5 reports the results of the baseline model described in eq. (1) that is a panel regression for the full sample over the period 2003-2013 using COV_RATIO and its quadratic transformation (COV_RATIO2). In an additive form, the variables FUNDING \& ADMIN and INTERVENTION are also added to account for national characterization of DIS across the sample and over time. We interact all the variables of interest with the dummies pre-crisis and crisis and exclude co-insurance due to collinearity. We also include in the model the control variables related to bank-specific and country-specific factors, plus the dummy crisis.

\section{[Insert Table 5 about here]}

Focusing on the results in panel A (Types of banks) evidence suggests the presence of a significant inverse U-shaped relationship between coverage and bank stability for 'All banks'. ${ }^{11}$

This is also illustrated by the fitted values plotted in Figure 1, both in the pre-crisis and crisis period.

\footnotetext{
${ }^{11}$ We carry out the same test for the following three subsamples: 1) with quarterly data; 2) with consolidated data; and 3) excluding Germany. Results are qualitative similar to those presented and omitted for brevity.
} 
[Insert Figure 1 about here]

Angkinand and Wihlborg (2010) provide similar results in a study focusing on 52 emerging and developing European and Asian countries in 1997-2003. Our findings in the first column 'All banks' imply that high level of deposit coverage, especially during crisis periods, in an attempt to limit systemic runs, could in fact encourage bank risk-taking. Thus, caution should be paid in setting a suitable level of deposit coverage to real GDP per capita.

The identified quadratic relationship allows us to calculate the turning point and estimate that during the crisis period the level of coverage (not in natural logarithm) at which the Z-score starts diminishing is 3.6 times the real GDP per capita. ${ }^{12}$ In our sample at the end of 2013 , all Eastern European countries as well as Portugal (6.33), Greece (6.06), Malta (5.81), Cyprus (5.26), Italy (3.91), Spain (4.48) exhibit coverage ratios above the identified turning point and country differences increased after 2010, in light of the common coverage equal to $€ 100,000$ per depositor (see Table 3 ). Such evidence raises concerns about the potential distortions that deposit coverage heterogeneity among European countries may have in the long-run.

In periods of financial instability, the role of deposit insurance is considered by the authorities as an effective mechanism to prevent bank runs. However, implementing upward adjustments of coverage over time ignoring GDP and inflation may imply that depositors 'slack off' their discipline, leaving room for risky bank conduct that needs to be adequately prevented through tighter supervision. Indeed, the coverage limit should not be too low to create incentives for pre-emptive depositor runs and not too high to discourage large depositors and sophisticated creditors to discipline their bank. For the remaining aggregate DIS variables, we find that FUNDING \& ADMIN and

\footnotetext{
${ }^{12}$ For example, if the average GDP_PC in EU27 over 2008-13 is equal to $€ 24,136$ and the turning point is 3.6, the $€$ amount of deposit insurance from which bank stability starts to decrease corresponds to around $€ 87,000$.
} 
INTERVENTION, when significant are negative consistently with the expectations set out in our hypotheses $H 2$ and $H 3$.

Table 5, panel A, also reveals that more capitalized banks (as expressed by the control variable ETA) and with a greater dependence from customer deposits (DEP_TA), tend to be more stable and sound, possibly because of the greater degree of discipline exerted by shareholders and depositors on banks' conduct. Consistently with Angkinand and Wihlborg (2010), we verify whether shareholders' risk-taking incentives are reduced with increased equity financing, whose exogenous nature is due to capital requirements. The results concerning our measure of the reliance on bank deposits (DEP_TA) appear in line with Anginer et al. (2014), as higher funding dependency from bank deposits alleviates bank risk. As expected, an increase in CIR (i.e. lower efficiency) corresponds to a reduction in bank stability; although this latter seem to be increasing with size and banking market concentration (HHI). The literature of concentration and stability in banking is not straightforward (Udhe and Heimeshoff, 2009). The positive and significant coefficient of the variable HHI, lends support to the "concentration-stability" view, which suggests that larger banks in concentrated banking systems may increase profits and decrease financial fragility by providing higher capital buffers that safeguard them against external shocks. Banking markets characterised by a handful of large institutions, are also expected to be easier to supervise and monitor.

Unsurprisingly, a better quality of the loan portfolio, as reflected by decreasing values of the variable LLR_GL, is positively associated with bank stability. In all models, the coefficients of the variables representing economic growth $(\triangle \mathrm{GDP})$ and institutional quality, as proxied by GPD_PC, when significant are positive, as expected. The role played by national institutional settings in mitigating or aggravating the potential for banks' moral hazard related to deposit insurance is of critical interest in the empirical analysis. Consistently with Hovakimian et al. (2003), Cull et al. (2005), and Demirgüç-Kunt et al. (2006), our results indicate that countries with a strong institutional environment are not affected by additional instability due to deposit insurance adoption. However, 
they may become unstable if the entire safety net design is inadequate and/or supervision and prudential regulation are weak. ${ }^{13}$

Table 5, panel A, also reports the results by business models (commercial vs cooperative and savings), size (small vs large) and degree of dependency from customer deposits. We find evidence that the U-shaped relationship between the coverage ratio and stability holds for all bank types. The magnitude of the coefficients, however, suggests that bank behaviour can differ considerably across business models. This seems evident during the crisis as the turning point value of the coverage ratio is equal to 4.25 for commercial banks and 3 for cooperative and savings, thus implying that these latter became riskier for lower levels of the ratio during the crisis. One possible explanation is that commercial banks typically have a greater degree of asset diversification and governance mechanisms more subject to market discipline compared to their mutual and savings counterparts. The coefficients of FUNDING \& ADMIN and INTERVENTION are significant and show the expected signs for the sub-sample of cooperative and savings banks, indicating the relevance that these additional DIS design mechanisms may have in curbing moral hazard of which the so-called stakeholder-oriented banks are not immune.

Evidence of a non-linear effect of COV_RATIO is also found for large banks during the crisis period, and the point at which their stability starts to decline equals 5.71. For large banks the relationship between DIS features and stability can be related to 'too-big-to fail' arguments and the presence of more intense external monitoring and supervision. Additionally, in highly concentrated banking systems, dominated by few large banks, higher deposit coverage ratios may be suitable to prevent bank runs. This evidence contrasts with the conventional idea that deposit insurance benefits more small riskier banks (Demirgüç-Kunt et al., 2006). For these latter we find that FUNDING \&

\footnotetext{
${ }^{13}$ We also carried out a test excluding the country-level control variables (HHI, $\Delta$ GDP, and GDP_PC) and using country fixed effects instead, in addition to bank fixed-effects. Results remain unchanged and are available upon request.
} 
$A D M I N$ mechanisms as well as the powers of intervention of the deposit insurer are essential to maintain their stability, especially in times of financial turmoil.

We also find that in normal times the non-linear effect of coverage limits is only significant for banks with low reliance on customer deposits. During crisis, there is evidence of non-linearities for both groups of banks, however the magnitude of the coefficients suggests that the effect is slightly stronger for banks with the lowest dependency on traditional deposits. However the turning points are not very different: 2.82 (2.73) for banks with the lowest (highest) dependency. Furthermore, in the case of greater reliance on customer deposits, we find that the structuring of the characteristics of funding, administration and intervention powers of DIS play an important role in counteracting instability due to bank moral hazard, especially during financial crises.

Table 5, panel B (Operating environment) shows that at least during periods of crisis, there is evidence of an inverse U-shaped relationship between the variables of interest, for banks located in 'no-GIIPS countries', that is the subsample that excludes Greece, Ireland, Italy, Portugal, and Spain. In particular, while in healthy economies in normal times deposit coverage contributes positively to bank stability, in crisis periods, if excessive, it may yield the opposite result (the turning point is 7.65 times the real GDP_PC). We also find support to $H 2$ and $H 3$, as expressed by the negative and significant coefficients of the variables FUNDING \& ADMIN and INTERVENTION. This seems to indicate that even in the healthiest countries, poorly-designed DIS can weaken incentives for good governance for banks and lead to a deterioration in the soundness of the banking system. Similarly, for banks operating in strongly bank -oriented financial systems, excessive deposit coverage ratios can result in losses in terms of stability, especially in stormy times; however, the turning point is a relatively high 7.62 . 
The last two columns of Panel B show the estimates obtained according to the level of supervisory power for the $27 \mathrm{EU}$ countries. ${ }^{14}$ Our evidence indicates the presence of quadratic relationships in the pre-crisis period only for banks located in countries where supervisors' power is below average; while, unexpectedly, the effect of deposit insurance is always positive and not quadratic in the crisis period. In countries with a low sophistication of supervisory power, the deposit insurer's intervention capabilities are important in containing bank instability, especially in difficult times. In these environments, size appear to be associated with a lower degree of stability, probably due to a lower effectiveness of the supervision activity. In countries where the supervisory power is greatest, it becomes important to carefully establish deposit coverage levels that minimize moral hazard incentives.

\subsection{Tests for the individual effects of DIS's selected features}

Table 6 reports the results for the full sample over 2003-2013. First, we run the model described in eq. (2) considering as target variables the three aggregate variables COVERAGE, FUNDING \& ADMIN, and INTERVENTION (column I). Then, in models (II), (III), and (IV), we disaggregate them alternatively into their single components. All models include the control variables related to bank- and country-specific factors, plus the crisis dummy.

Our findings show positive, although decreasing, significant coefficients for the variable COVERAGE (COV_SUM), both before and after the outbreak of the financial crisis, as shown in models (I) and (III). In model (IV) COV_SUM is positive and significant only when it is interacted with the crisis dummy. This finding is in contrast with our expectation, and suggests that deposit

\footnotetext{
${ }^{14}$ Bank supervisory power is a proxy for the strength of supervision in each country (see e.g. Buch and DeLong, 2008 for an application). This variable ranges from 0 to 14 , where the higher the score, the greater the supervisory power. Data on supervisory power are collected from the cross-country database on bank regulation and supervision compiled by the World Bank (2003, 2007, and 2012).
} 
insurance reduces bank risk especially during the recent crisis, and it is in line with Anginer et al. (2014). Similar evidence is provided by Liu et al. (2016) who argue that deposit insurance helps stabilize volatile markets, as evidenced during the financial crisis. However, the single components of the variable COV_SUM in model (II), suggest that these results are driven by the variable NO_COINS. As expected, high levels of deposit coverage (HIGH_COV) weakened more bank stability during the crisis period; while pre-crisis the coefficient is negative and insignificant. Similar results are obtained by Demirgüç-Kunt and Detragiache (2002).

The absence of co-insurance appears to make banks less risky, given the positive sign of the coefficients in both periods and the higher magnitude registered in the crisis period. Such evidence contrasts with Demirgüç-Kunt and Detragiache (2002), Hovakimian et al., (2003), and more recently Liu et el. (2016). We also find that the positive effect exerted by NO_COINS on bank stability dominates that of the dummy HIGH_COV.

In theory, the absence of co-insurance should increase bank risk (Barth et al., 2013). One possible reason for these unexpected results is that episodes of bank runs, which cause instability of sound banks may be aggravated by the presence of co-insurance mechanisms, as it seems to emerge from the magnitude of the coefficient of the variable NO_COINS *crisis. As co-insured depositors perceive that their deposits are at risk, they will run to banks in order to avoid to be only partially reimbursed in case of bank failure. Such a phenomenon may be more pronounced in countries where deposits represent a relatively larger portion of bank liabilities. In recent years co-insurance has been largely abandoned in many countries (see Table 3) as set out in the 2009/14/EC Directive. Thus our results confirm the validity of the removal of the variable co-insurance from the remaining empirical analysis.

Based on our first research hypothesis, our findings suggest that more protective DIS do not overall intensify bank risk-taking. However, we find that this effect is brought about by relatively low levels of coverage and the absence of co-insurance mechanisms, whose presence may undermine 
depositors' trust in the safety and soundness of their banks. These results appear to hold in different market scenarios, calm and turbulent, but show different degrees of intensity.

The second DIS aggregate variable, FUNDING \& ADMIN, is significant only during the crisis period and presents the expected negative sign in all models. This suggests that, in line with Demirgüç-Kunt and Detragiache (2002), funding and administration of DIS significantly reduce the soundness of banks possibly by inducing greater bank moral hazard. Focusing on the decomposition of FUNDING \& ADMIN (column III), with only one exception (GOV_ADMIN), the significant variables are negative. Our results provide supportive elements for the IADI's recommendations (2013c) and recent rules introduced by the novel 2014/49/EC Directive concerning the effectiveness of ex-ante funding mechanism as a risk minimizing DIS feature. Regarding the absence of riskadjusted premia in the crisis period, our results are in line with Liu et al.'s (2016), who also find evidence on the effectiveness of risk-adjusted premia as a risk-minimizing feature.

In contrast, we observe a positive and significant coefficient of the feature GOV_FUND, but only during the pre-crisis period. Reliance on government funding may have a double, contrasting effect: on the one hand it provides incentives to moral hazard if banks are not properly charged for the insurance of the deposits collected; on the other, it prevents bank runs which may originate from mistrust of depositors in the ability of the insurer to pay its liabilities. However, in both cases discipline on bank behaviour is severely compromised (Kane, 1991) and long-run economic growth opportunities may be negatively affected. An exception to these adverse consequences induced by generous government-funded deposit insurance might be found, as noted by Cull et al. (2005), in countries where the rule of law is well established and bank supervisors are granted sufficient discretion and independence. Equally, government funding should be considered essential (Morrison and White, 2011), or act as additional backup funding (Garcia, 1999), when the soundness of the financial sector is uncertain. 
Overall, according to our second research hypothesis, we find that only in the crisis period those DIS that are more inclined to encourage bank moral hazard negatively affect bank soundness. Results are especially robust in countries characterized by the absence of risk-adjusted premia.

The third aggregate variable, INTERVENTION, is always significant and has the expected negative sign in all models. This suggests that bank risk increases when the administration of the national DIS lacks itself the power to cancel, intervene or take legal actions against the managers of failed banks.

Before the Directive 94/19/EC (the Deposit Guarantee Scheme Directive, DGSD) and the Directive 2014/59/EU (the Bank Recovery and Resolution Directive, BRRD) establishing the Single Resolution Mechanism (SRM), the set-up of such powers was generally left to national discretion: powers were held by or shared among different national supervisory authorities, the judicial system and the DIS. After the outburst of the global financial crisis, the clarity of roles, coordination and appropriate and timely information sharing have become crucial to ensure the effectiveness of actions among all the components of the financial safety net. With the recent directives, the European legislator has provided a more precise definition of the powers of the deposit insurer and on the sharing of the same between the different authorities that are part of the national and supranational financial safety net. The regulatory harmonization efforts aim to eliminate national fragmentation although there are still some grey areas due to the national discretions allowed by the regulations.

Looking at the single components of the variable INTERVENTION, we find significant and negatively increasing coefficients for the variables NO_INTERV and NO_CANCEL in the examined periods. In addition, NO_LEGALPWR is significant only in the period preceding the outburst of the financial crisis and shows the expected negative sign. In sum, according to our third hypothesis, we find significant support to the negative effects of DIS' features on bank stability. 
Such powers are generally held by national supervisory authorities or are strictly shared by DIS with bank supervisors and consistently exerted by the deposit insurers. ${ }^{15}$ Looking at the single components of the variable INTERVENTION, we find significant and negatively increasing coefficients for the variables NO_INTERV and NO_CANCEL in the examined periods. In addition, NO_LEGALPWR is significant only in the period preceding the outburst of the financial crisis and shows the expected negative sign.

In sum, according to our third hypothesis, we find significant support to the negative effects of DIS' features on bank stability. The possibility of the deposit insurance authority to intervene a bank, the ability of the deposit insurer to cancel banks, and in part, the possibility of the authorities to take legal action against banks' directors/officials, seem to be associated with higher bank soundness, regardless of the market conditions. ${ }^{16}$

[Insert Table 6 about here]

\subsection{Accounting for blanket guarantees}

During the period 2008 to 2010 , eight countries ${ }^{17}$ temporarily introduced blanket guarantees, either by law (as in Denmark and Ireland), or by public declaration of the government (as for example in Germany, Greece and Hungary) stating that all private savings were guaranteed.

\footnotetext{
${ }^{15}$ It is worth noting that especially in times of crisis, the existence of an interventionist set-up may render banks riskier as the threat of cancellation from the DIS or other forms of intervention on bank management may, on the one hand, push managers to engage in whitewashing practices to hide risky activities and/or, on the other hand, promote bank runs if depositors feel that their deposits are becoming unsafe. In this latter case, even sound banks can be threatened by the depositors' fear that banks may be in danger as news of intervention of the deposit insurance agency spread out.

${ }^{16}$ Results also hold with an alternative specification where DIS aggregate features are interacted with the sole dummy CRISIS.

${ }^{17}$ Namely, Austria, Denmark, Germany, Greece, Hungary, Ireland, Slovakia, and Slovenia.
} 
In this section we verify whether bank exposure to risk is amplified by the introduction of unlimited guarantees. Table 7 provides the results on the effect of blanket guarantees on banks' stability over the period 2008-2010. The dichotomous variable BLANKET takes the value of one for those countries which fully guaranteed their national deposits in the most frantic period of the crisis. As key explanatory aggregate variables we consider FUNDING \& ADMIN and INTERVENTION and exclude the aggregate coverage variable as the blanket already guarantees full coverage by definition. According to the empirical results, this temporary emergency measure, sizably increased the banks' soundness avoiding that panic among depositors could affect even healthy banks, as suggested by Garcia (1999).

[Insert Table 7 about here]

\subsection{Risk taking incentives and deposit insurance reforms over 2008-2010}

We also consider the effects of the magnitude of regulatory changes occurred in deposit insurance from 2008 to 2010 on bank stability vis à vis the pre-crisis national levels of coverage. We categorize as 'AFFECTED' ('unaffected') those banks located in countries that experienced a change in COV_RATIO equal or above (below) the mean of all changes occurred in 2010.

To test whether the effect of changes in deposit coverage varied according to the level existing in each EU country prior to 2008, we employed the variable HIGH_COV07, which takes the value of 1 if the coverage ratio in 2007 is equal or above the annual mean values, 0 otherwise (see Table 8). We further interact the two variables (AFFECTED*HIGH_COV07) to isolate those countries with a coverage ratio exceeding the mean in 2007 and that additionally experienced a change in coverage above the mean in 2010. This subsample of countries, which should experience the highest moral hazard risk, represents the treatment sample. 
We use an ordinary least square regression and control for year and country fixed-effects. The country fixed effects net out any time-invariant unobserved country-specific factors, while the year fixed effects difference away trends that influence affected and unaffected banks. We use a clusterrobust sandwich estimator where the standard errors allow for interbank correlation through time, relaxing the usual requirement for the observations to be independent across and within individual banks.

Table 8 shows that the variables AFFECTED and HIGH_COV07 have a strong, positive and significant effect on banks' stability. Their interaction, in contrast, seems to have the opposite effect. These findings are in line with our previous analyses: large changes in coverage during the crisis and high level of COV_RATIO prior to the crisis per se enhance bank stability, but the too generous combined provisions of these two variables can be detrimental to banks' soundness even though the overall effect remains positive in turbulent times.

[Insert Table 8 about here]

\section{Robustness tests}

In line with the literature, we test the robustness of our main findings by using different measures of bank stability (Casu and Sarkisyan, 2010; Schaeck and Cihak, 2014). We first regress the independent and control variables employed in the baseline model against the three components of the Z-score: ETA; ROAA and oROAA (see columns 1-3 of Table 9). Then, we use two further proxies of the Z-Score: the TIER1 RATIO and the quality of the loan portfolio (LLR_GL).

Interestingly, Table 9 shows that in the crisis period the presence of a high coverage ratio makes bank profitability more volatile, as proxied by the standard deviation of ROAA. Other results on capitalization levels (ETA) and level of intervention are usually consistent with our main findings reported in Table 5. 
[Insert Table 9 about here]

In addition, with reference to the variable LLR_GL, we find that excessive levels of deposit coverage determine an increase in bank risk, a possible cause of instability, most likely due to reckless lending policies. The weakness of the intervention powers of the depository insurer also contributes to increasing the bank's riskiness. The quadratic effect of the deposit insurance coverage is not found when TIER1 RATIO is the dependent variable, as in the case of ETA. Unexpectedly, we find that, albeit weakly, the FUNDING \& ADMIN variables present a positive and meaningful sign, both before and after 2008. Looking at the effect of the individual components of the FUNDING \& ADMIN variable, not reported here for the sake of brevity, we find that banks are more able to deal with risks with their capital in two circumstances: when the financing and administration of DIS are public during the period preceding the outbreak of the global financial crisis; and when insurance premium systems are not risk adjusted after 2008. This last result appears compatible with those circumstances in which the worsening of the macroeconomic situation and the consequent increase in risks do not translate into an increase in insurance costs, thus leaving to banks more room to increase regulatory capital endowments. A similar situation occurs when funding and management of DIS does not fall on participating banks. ${ }^{18}$

\footnotetext{
${ }^{18}$ Before the deposit coverage harmonization in EU, the host-country control rule for foreign branches and subsidiaries could potentially interfere with the incentives created by the national regulations in terms of deposit coverage. Data available on foreign branches are very poor. However, to at least partially address this issue, we isolate those EU countries in which European banking groups could have had incentives to open subsidiaries, due to their lower level of deposit insurance before 2009, such as Central and Eastern European Countries. We then tested whether this potential "arbitrage" affected bank stability, but we found no empirical evidence to support this hypothesis. We thank an anonymous referee for suggesting this test. These findings, omitted for brevity, are available with the authors upon request.
} 
We also check and found evidence to the parallel trend assumption, as for example in Calderon and Schaeck (2016), that holds that in absence of treatment (the increase in deposit insurance throughout 2008-2010) changes in bank stability are similar for banks benefiting from pre-existing high or low deposit coverage. Additionally, following the authors, we adopt a Cox (1972) proportional hazard model to verify that the increase of deposit insurance coverage above average over the period 2008-2010, proxied by the treatment variable AFFECTED, and the introduction of a blanket guarantee (BLANKET) are exogenous with respect to bank stability, measured by the Zscore.

The independent variable coefficient denotes the hazard of observing above average deposit insurance coverage increase and blanket guarantees. Our analysis is conducted at country level. Countries are dropped from the analysis once they experience the intervention of interest. Our sample period covers the period 2003 - 2010 as deposit coverage increases and blanket guarantees were made within 2010. The measure of bank stability, the Z-score, remains insignificant, thus suggesting that bank stability is not driving the variables AFFECTED and BLANKET. The results, not included in Table 10, hold even introducing the variables FUNDING \& ADMIN and INTERVENTION.

[Insert Table 10 about here]

\section{Conclusions}

This paper sets out to explore the effect of national deposit insurance features on bank stability in Europe and to empirically verify the existence of non-linearities in the relationship between coverage and bank stability both in crisis and normal times. We conjecture that just focusing on the role of coverage and its optimal value when assessing the impact of deposit insurance on risk-taking incentives is too restrictive. The features of DIS are generally expected to enhance depositors' confidence. Although this may not be at work during periods of high instability, such as at the peak 
of the crisis when the effects may even be reversed, in normal times too generous schemes may promote bank risk-taking and make financial systems vulnerable to crises.

We employ a detailed set of European Deposit Insurance Schemes (DIS) features for 27 EU countries and distinguish between a pre-crisis (2003-2007) and financial and euro sovereign debt crisis period (2008-2013). We test three main hypotheses based on the premises that bank stability will decrease when deposit insurance is excessively protective, if the structure of the funding and administration of national DIS generate moral hazard incentives and when deposit insurers have no adequate power of intervention on banks.

The European case is of particular interest because national governments for 15 years, up until the introduction of the 2009 and 2014 Directives, benefited from significant discretion in the DIS design and there was only a minimum degree of harmonisation across European countries. Much more shared common rules and the establishment of a European Deposit Insurance Scheme (EDIS), the third pillar to complete the Banking Union, have become essential to foster financial integration and stability in Europe.

For our empirical analysis we employ fixed-effects panel data models with lagged explanatory variables to alleviate possible simultaneity problems alongside a battery of thorough robustness checks and multiple specifications. Our results suggest that more protective DIS do not necessarily lead to greater bank risk. However, during the crisis some features that generate moral hazard incentives can decrease bank stability. We find an inverse U-shaped relation with bank stability decreasing at high levels of coverage during the crisis period. Our evidence also indicate that the introduction of temporary measures like blanket guarantees are crucial to avoid panic among depositors and restore stability in turbulent times.

Overall, this paper provides novel evidence that DIS design matters when assessing the impact of deposit insurance and stability, and proves that ignoring the simultaneous and incremental effects of DIS features may lead to inaccurate and partial conclusions. In particular, our empirical analysis 
demonstrates that the net result of the mix of deposit insurance features on banks' stability depends on whether the safety net effect can outweigh the various moral hazard incentives of the DIS features. Our evidence also demonstrates that the generosity of deposit insurance coverage is not detrimental, per se, because it restrains the potential for bank runs but it should progressively fine-tune itself and with the other features characterizing a DIS.

Compared to bank managers and shareholders, depositors are typically less able to distinguish between safe and unsafe banking institutions. One of the key lessons from the recent financial turmoil is that depositors have limited ability to exercise market discipline or mitigate moral hazard during a crisis. In terms of policy, our study has allowed to retrospectively assess the goodness of regulatory novelties introduced by the latest (2014) EU Directive, thus providing evidence of their suitability in preserving bank soundness. It has also demonstrated that the stabilizing effect of deposit insurance can be different along different bank characteristics and business models and is influenced by the environment within which it operates. This has been recognised in recent relevant policy documents (e.g. IADI, 2013; 2014) and includes macroeconomic conditions as well as other country-specific aspects, such as the strength of the sovereign, the financial system structure, and the prudential regulatory settings.

One of the main implications for regulators from our study is that an optimal DIS that minimizes moral hazard incentives may require a dynamic approach. This is particularly important in light of the needed progress in the third pillar of the Banking Union for the eurozone countries that implies a single deposit insurance scheme and elements of risk sharing. Ideally, policy-makers and regulators should review and adapt coverage limits taking into account the economic cycle and considering current and future trends in the supply of and demand for traditional banking products and, crucially, their quality. However, announcements of reduction of coverage may not be easy to implement particularly in bank-based financial systems. 
Overall, the key message of this study is that DIS should focus more on maintaining financial stability and be sufficiently flexible to account for local conditions. Despite the process of harmonisation, eurozone countries are still quite diverse in terms of overall riskiness of their banking sectors and in their institutional settings, culture, history as well as legal and judicial frameworks. This suggests that there could be potential vulnerabilities in the creation of a common EU deposit insurance framework based on a 'one size fits all'. 


\section{References}

Acharya, V. V. 2009. "A theory of systemic risk and design of prudential bank regulation.” Journal of Financial Stability 5(3): 224-255.

Aikman D., J. Bridges, S. Burgess, R. Galletly, I. Levina, C. O’Neill, and A. Varadi. 2018. "Measuring risks to UK financial stability." Staff Working Paper no 738, Bank of England.

Anginer, D., A. Demirguc-Kunt, and M. Zhu. 2014. "How does deposit insurance affect bank risk? Evidence from the recent crisis." Journal of Banking and Finance 48: 312-321.

Angkinand, A., and C. Wihlborg. 2010. "Deposit insurance coverage, ownership, and banks' risktaking in emerging markets." Journal of International Money and Finance 29(2): 252-274.

Bank for International Settlements (BIS). 2009. 79th Annual Report. Basel, June.

Barth, J. R., Jr G. Caprio, and R. Levine. 2013. "Bank regulation and supervision in 180 countries from 1999 to 2011." Journal of Financial Economic Policy 5(2): 111-219.

Barth, J. R., Jr G. Caprio, and R. Levine. 2004. "Bank regulation and supervision: what works best?" Journal of Financial Intermediation 13(2): 205-248.

Becchetti, L., R. Ciciretti, and A. Paolantonio. 2016. "The cooperative bank difference before and after the global financial crisis." Journal of International Money and Finance, vol. 69: 224246.

Beck T., and L. Laeven. 2006. "Resolution of failed banks by deposit insurers: cross-country evidence.” World Bank Policy Research Working Paper No. 3920.

Beck T., H. Hesse, T. Kick, and N. von Westernhagen. 2009. "Bank ownership and stability: evidence from Germany.” Bundesbank Working Paper Series.

Boyd J. H., G. De Nicoló, and A. M. Jalal. 2006. "Bank risk-taking and competition revisited: New theory and new evidence”. IMF Working Paper 06/297. International Monetary Fund.

Buch, C.M., and G. DeLong. 2008. "Do weak supervisory systems encourage bank risk-taking?" Journal of Financial Stability 4, 23-39.

Calderon, C., and K. Schaeck. 2016. "The effects of government interventions in the financial sector on banking competition and the evolution of zombie banks." Journal of Financial and Quantitative analysis 51(4): 1391-1436.

Calomiris, C. W. 1990. "Is deposit insurance necessary? A historical perspective." The Journal of Economic History 50(2): 283-295.

Calomiris, C. W., and M. Jaremski. 2016. "Deposit insurance: Theories and facts." Annual Review of Financial Economics 8: 97-120. 
Casu, B. and A. Sarkisyan 2013. "Retained interests in securitizations and implications for bank solvency." ECB Working Paper Series 1538.

Chiaramonte, L., E. Croci, and F. Poli. 2015a. "Should we trust the Z-score? evidence from the European banking industry”. Global Finance Journal 28: 111-131.

Chiaramonte, L., F. Poli, and M. E. Oriani. 2015b. “Are cooperative banks a lever for promoting bank stability? Evidence from the recent financial crisis in OECD countries." European Financial Management 21(3): 491-523.

Chiaramonte, L., H. Liu, F. Poli, and M. Zhou. 2016. "How accurately can Z-score predict bank failure?" Financial Markets, Institutions \& Instruments 25(5): 333-360.

Cordella, T., and E. L. Yeyati. 2002. "Financial opening, deposit insurance, and risk in a model of banking competition." European Economic Review 46(3): 471-485.

Cox, D. 1972. "Regression Models and Life Tables.” Journal of the Royal Statistical Society 34: 187220.

Cull, R. J., L. W. Senbet, and M. Sorge. 2005. "Deposit insurance and financial development." Journal of Money, Credit, and Banking 37(1): 43-82.

De Nicoló, G. 2000. "Size, charter value and risk in banking: An international perspective." International Finance Discussion Papers No. 689.

Delis M. D., K. C. Tran, E. G. Tsionas. 2012. "Quantifying and explaining parameter heterogeneity in the capital regulation-bank risk nexus." Journal of Financial Stability, 8(2), 57-68.

Demirgüç-Kunt, A., and E. Detragiache. 2002. "Does deposit insurance increase banking system stability? An empirical investigation.” Journal of Monetary Economics 49(7): 1373-1406.

Demirgüç-Kunt, A., and H. Huizinga. 1999. "Market discipline and financial safety net design." World Bank Policy Research Working Paper No. 2183.

Demirgüç-Kunt, A., and H. Huizinga. 2004. "Market discipline and deposit insurance." Journal of Monetary Economics 51(2): 375-399.

Demirgüç-Kunt, A., and E. J. Kane. 2002. “Deposit insurance around the globe: Where does it work?” The Journal of Economic Perspectives 16(2): 175-195.

Demirgüç-Kunt, A., and R. Levine. 2000. "Bank concentration: cross-country evidence.” World Bank Working Paper No. 27828.

Demirguc-Kunt, A., E. J. Kane, and L. Laeven. 2006. "Determinants of deposit-insurance adoption and design." World Bank Working Paper.

Demirgüç-Kunt, A., E. J. Kane, and L. Laeven. 2015. "Deposit insurance around the world: A comprehensive analysis and database.” Journal of Financial Stability 20: 155-183. 
Diamond, D. W., and P.H. Dybvig. 1983. "Bank runs, deposit insurance, and liquidity.” Journal of Political Economy 91(3): 401-419.

Dreyfus, J. F., A. Saunders, and L. Allen. 1994. "Deposit insurance and regulatory forbearance: Are caps on insured deposits optimal?" Journal of Money, Credit and Banking 26(3): 412-438.

European Commission. 2004. Report on Minimum Guarantee Level of Deposit Guar-antee Schemes Directive 94/19/EC, (http://ec.europa.eu/internal market/bank/docs/guarantee/report en.pdf), annex available from: (http://ec.europa.eu/internal market/bank/docs/guarantee/annexes en.pdf).

European Commission. 2010. Impact Assessment for Proposal on Deposit Guar-antee Schemes, (http://ec.europa.eu/internal market/bank/docs/guarantee/20100712_ia_en.pdf), annex II available from: (http://ec.europa.eu/internalmarket/bank/docs/guarantee/jrc-annex2_en.pdf).

European Commission. 2011. JRC Report under Article 12 of Directive 94/19/EEC, (http://ec.europa.eu/internal market/bank/docs/guarantee/jrc-rep_en.pdf), annex I and II available from: (http://ec.europa.eu/internal_market/bank/docs/guarantee/jrc-annex1_en.pdf) and (http://ec.europa.eu/internal market/bank/docs/guarantee/jrc-annex2_en.pdf).

Financial Stability Board (FSB). 2012. Thematic Review on Deposit Insurance Systems. (http://www.financialstabilityboard.org/publications/r_120208.pdf).

Fiordelisi, F. and D. S. Mare. 2014. "Competition and financial stability in European cooperative banks." Journal of International Money and Finance 45: 1-16.

Forssbaeck, J. 2011. “Ownership structure, market discipline, and banks' risk-taking incentives under deposit insurance." Journal of Banking and Finance 35(10): 2666-2678.

Garcia, M. G. 1999. "Deposit insurance: A survey of actual and best practices.” International Monetary Fund Working Paper No. 54.

García-Marco, T., and M. D. Robles-Fernández. 2008. "Risk-taking behavior and ownership in the banking industry: The Spanish evidence.” Journal of Economics and Business 60(4): 332-354.

Gropp, R., and J. Vesala. 2004. “Deposit insurance, moral hazard and market monitoring.” Review of Finance 8(4): 571-602.

Gropp, R., C. Gruendl, and A. Guettler. 2013. "The impact of public guarantees on bank risk-taking: Evidence from a natural experiment." Review of Finance 18(2): 457-488.

Gropp, R., H. Hakenes, and I. Schnabel. 2010. "Competition, risk-shifting, and public bail-out policies." The Review of Financial Studies 24(6): 2084-2120.

Grossman, R. S. 1992. "Deposit insurance, regulation, and moral hazard in the thrift industry: evidence from the 1930's." The American Economic Review 82 (4): 800-821. 
Hesse, H., and M. Čihák. 2007. “Cooperative banks and financial stability.” International Monetary Fund Working Paper No. 2.

Hovakimian, A., E.J. Kane, and L. Laeven. 2003. "How country and safety-net characteristics affect bank risk-shifting.” Journal of Financial Services Research 23(3): 177-204.

International Association of Deposit Insurers (IADI). 2013a. "Enhanced guidance for effective deposit insurance systems: Deposit insurance coverage.” Basel.

International Association of Deposit Insurers (IADI). 2013b. "Enhanced guidance for effective deposit insurance systems: Mitigating moral hazard." Basel.

International Association of Deposit Insurers (IADI). 2013c. "General guidance on early detection and timely intervention for deposit insurance systems." Basel.

International Association of Deposit Insurers (IADI). 2014. "IADI core principles for effective deposit insurance systems.” Basel.

Ioannidou, V. P., and M. F. Penas. 2010. "Deposit insurance and bank risk-taking: Evidence from internal loan ratings." Journal of Financial Intermediation 19(1): 95-115.

Kane, E. J. 1995. "Three paradigms for the role of capitalization requirements in insured financial institutions." Journal of Banking and Finance 19(3): 431-459.

Kane, E.J. 1991. "Econometric Estimates of the 1986-1989 Time Profile of Taxpayer Losses in the SandL Insurance Mess” with an Appendix prepared by Min-Teh Yu, Final project report, Congressional Budget Office, Washington DC (February 18).

Karels, G. V., and C.A. McClatchey. 1999. "Deposit insurance and risk-taking behaviour in the credit union industry." Journal of Banking and Finance 23(1): 105-134.

Laeven, L. 2002. "Bank risk and deposit insurance." The World Bank Economic Review 16(1): 109137.

Laeven, L., and R. Levine. 2009. “Bank governance, regulation and risk taking.” Journal of Financial Economics 93(2): 259-275.

Laeven, L., and F. Valencia. 2012. "The use of blanket guarantees in banking crises.” Journal of International Money and Finance 31(5): 1220-1248.

Lambert, C., F. Noth, and U. Schüwer. 2017. "How do insured deposits affect bank risk? Evidence from the 2008 Emergency Economic Stabilization Act.” Journal of Financial Intermediation 29, 81-102.

Liu, L., G. Zhang, and Y. Fang. 2016. "Bank credit default swaps and deposit insurance around the world.” Journal of International Money and Finance 69: 339-363. 
Mare, D.S. 2015. "Contribution of macroeconomic factors to the prediction of small bank failures." Journal of International Financial Markets, Institutions \& Money 39: 25-39.

Merton, R. C. 1978. "On the cost of deposit insurance when there are surveillance costs." Journal of Business 51 (3): 439-452.

Morrison, A. D., and L. White. 2011. "Deposit insurance and subsidized recapitalizations.” Journal of Banking and Finance 35(12): 3400-3416.

Nys, E., A. Tarazi, and I. Trinugroho. 2015. "Political connections, bank deposits, and formal deposit insurance.” Journal of Financial Stability 19: 83-104.

Pennacchi, G. 1987. “A re-examination of the over-(or under-) pricing of deposit insurance.” Journal of Money, Credit and Banking 19(3): 340-360.

Pennacchi, G. 2006. "Deposit insurance, bank regulation, and financial system risks.” Journal of Monetary Economics 53(1): 1-30.

Schaeck, K. and M. Cihak. 2014. "Competition, Efficiency, and Stability in Banking." Financial Management, 43(1): 215-241.

Stiroh, K. J. 2004a. "Diversification in banking: Is noninterest income the answer?" Journal of Money, Credit and Banking, 36(5), 853-882.

Stiroh, K. J. 2004b. "Do community banks benefit from diversification?" Journal of Financial Services Research, 25(2-3), 135-160.

Udhe, A. and U. Heimeshoff. 2009. Consolidation in banking and financial stability in Europe: Empirical evidence" Journal of Banking and Finance, 33(1), 1299-1311.

Wheelock, D. C., and P. W. Wilson. 1995. "Explaining bank failures: Deposit insurance, regulation, and efficiency." The Review of Economics and Statistics 77 (4): 689-700.

World Bank. 2003. Bank Regulation and Supervision database, (https://www.worldbank.org/en/research/brief/BRSS).

World Bank. 2007. Bank Regulation and Supervision database, (http://siteresources.worldbank.org/INTRES/Resources/469232-

1107449512766/Banking_regulation_Survey_III_061008.xls).

World Bank. 2012. Bank Regulation and Supervision database, (http://siteresources.worldbank.org/EXTGLOBALFINREPORT/Resources/88160961346865433023/8827078-1347152290218/Bank_Regulation.xlsx).

Yeyati E. L., A. Micco. 2007. "Concentration and foreign penetration in Latin American banking sectors: Impact on competition and risk.” Journal of Banking and Finance, 31(6), 1633-164. 
Table 1 - Variable definitions and expected relationships vs bank stability

This table describes the explanatory variables used in our model and summarizes their hypothesized relationships with the dependent variable (bank stability).

\begin{tabular}{|c|c|c|c|}
\hline Variable name & Definition & Source & Expected sign \\
\hline \multicolumn{4}{|c|}{ DEPENDENT VARIABLE } \\
\hline Z-score & $\begin{array}{l}\text { The natural logarithm of the Z-score calculated as the } \\
\text { sum of equity to total assets (ETA) and return on } \\
\text { average assets (ROAA) scaled by the three-year } \\
\text { standard deviation of ROAA ( } \sigma \text { ROAA). }\end{array}$ & BankScope & / \\
\hline \multicolumn{4}{|l|}{ DESIGN FEATURES } \\
\hline COV_RATIO & $\begin{array}{l}\text { The natural logarithm of the Euros amount of } \\
\text { deposits refunded in case of bank failure scaled by } \\
\text { the real GDP per capita. }\end{array}$ & $\begin{array}{l}\text { World Bank BRS Survey } \\
\text { 2003, 2007, 2012; } \\
\text { European Commission } \\
\text { reports } 2004,2010,2011\end{array}$ & Negative \\
\hline COV_RATIO2 & The square of COV_RATIO. & Own computation & Positive/Negative \\
\hline HIGH_COV & $\begin{array}{l}\text { Equals } 1 \text { if the natural logarithm of the Euros amount } \\
\text { of deposits refunded in case of bank failure scaled by } \\
\text { the real GDP per capita (i.e. COV_RATIO) is equal } \\
\text { or above the annual mean values, } 0 \text { otherwise. }\end{array}$ & $\begin{array}{l}\text { World Bank BRS Survey } \\
\text { 2003, 2007, 2012; } \\
\text { European Commission } \\
\text { reports } 2004,2010,2011\end{array}$ & Negative \\
\hline NO_COINS & Equals 1 when there is no co-insurance, 0 otherwise. & $\begin{array}{l}\text { World Bank BRS Survey } \\
\text { 2003, 2007, 2012; } \\
\text { European Commission } \\
\text { reports } 2004,2010,2011\end{array}$ & Negative \\
\hline COVERAGE & Sum of HIGH_COV and NO_COINS. & Own computation & Negative \\
\hline GOV_FUND & $\begin{array}{l}\text { Equals } 1 \text { when solely government or jointly banks } \\
\text { and government provide the source of funding, } 0 \\
\text { when the funds are entirely provided by banks. }\end{array}$ & $\begin{array}{l}\text { World Bank BRS Survey } \\
\text { 2003, 2007, 2012; } \\
\text { European Commission } \\
\text { reports } 2004,2010,2011\end{array}$ & Negative \\
\hline NO_EXANTE & $\begin{array}{l}\text { Equals } 1 \text { for ex-post contribution, } 0 \text { for ex-ante } \\
\text { contributions. }\end{array}$ & $\begin{array}{l}\text { World Bank BRS Survey } \\
\text { 2003, 2007, 2012; } \\
\text { European Commission } \\
\text { reports } 2004,2010,2011\end{array}$ & Negative \\
\hline NO_RISKADJ & $\begin{array}{l}\text { Equals } 1 \text { when the premia are not risk-adjusted, } 0 \\
\text { otherwise. }\end{array}$ & $\begin{array}{l}\text { World Bank BRS Survey } \\
\text { 2003, 2007, 2012; } \\
\text { European Commission } \\
\text { reports } 2004,2010,2011\end{array}$ & Negative \\
\hline GOV_ADMIN & $\begin{array}{l}\text { Equals } 1 \text { if the insurance fund is administered solely } \\
\text { by the government or jointly by banks and } \\
\text { government, } 0 \text { otherwise. }\end{array}$ & $\begin{array}{l}\text { World Bank BRS Survey } \\
2003,2007,2012 ; \\
\text { European Commission } \\
\text { reports } 2004,2010,2011\end{array}$ & Negative \\
\hline FUNDING \& ADMIN & $\begin{array}{l}\text { Sum of GOV_FUND, } \\
\text { NO_RISKADJ and GOV_ADMIN. }\end{array}$ & Own computation & Negative \\
\hline NO_INTERV & $\begin{array}{l}\text { Equals } 1 \text { if the insurance authority has not the power } \\
\text { to intervene a bank, } 0 \text { otherwise. }\end{array}$ & $\begin{array}{l}\text { World Bank BRS Survey } \\
\text { 2003, 2007, 2012; } \\
\text { European Commission } \\
\text { reports } 2004,2010,2011\end{array}$ & Negative \\
\hline NO_CANCEL & $\begin{array}{l}\text { Equals } 1 \text { if the insurance authority has not the power } \\
\text { to cancel or revoke membership of deposit insurance } \\
\text { schemes for any participating bank, } 0 \text { otherwise. }\end{array}$ & $\begin{array}{l}\text { World Bank BRS Survey } \\
\text { 2003, 2007, 2012; } \\
\text { European Commission } \\
\text { reports } 2004,2010,2011\end{array}$ & Negative \\
\hline NO_LPWR & $\begin{array}{l}\text { Equals } 1 \text { if the authority cannot take legal action } \\
\text { against banks' directors/officials, } 0 \text { otherwise. }\end{array}$ & $\begin{array}{l}\text { World Bank BRS Survey } \\
\text { 2003, 2007, 2012; } \\
\text { European Commission } \\
\text { reports } 2004,2010,2011\end{array}$ & Negative \\
\hline INTERVENTION & $\begin{array}{l}\text { Sum of NO_INTERV, NO_CANCEL and } \\
\text { NO_LPWR. }\end{array}$ & Own computation & Negative \\
\hline BLANKET & $\begin{array}{l}\text { Equals } 1 \text { if the insurance authorities granted } \\
\text { unlimited coverage of bank deposits; } 0 \text { otherwise. }\end{array}$ & $\begin{array}{l}\text { EU Commission Staff } \\
\text { Working reports }\end{array}$ & Positive/Negative \\
\hline AFFECTED & $\begin{array}{l}\text { Equals } 1 \text { for banks located in countries which } \\
\text { experienced a change in the COV_RATIO equals or } \\
\text { above the mean of all changes occurred within } 2010 \text {, } \\
\text { and } 0 \text { otherwise. }\end{array}$ & Own computation & Negative \\
\hline
\end{tabular}




\begin{tabular}{|c|c|c|c|}
\hline HIGH_COV07 & $\begin{array}{l}\text { Equals } 1 \text { if the COV_RATIO in } 2007 \text { is equal or } \\
\text { above the annual mean values, } 0 \text { otherwise. }\end{array}$ & Own computation & Negative \\
\hline \multicolumn{4}{|c|}{ BANK CONTROLS } \\
\hline SIZE & Natural logarithm of total assets. & BankScope & Positive/Negative \\
\hline ETA & Equity to total assets. & BankScope & Positive \\
\hline DEP_TA & Total customer deposits to total assets. & BankScope & Positive/Negative \\
\hline $\mathrm{CIR}^{--2}$ & Cost-income ratio. & BankScope & Negative \\
\hline DIV & Non-interest income to net operating revenue. & BankScope & Positive \\
\hline LLR_GL & Loan loss reserves to gross loans. & BankScope & Negative \\
\hline \multicolumn{4}{|c|}{ COUNTRY CONTROLS } \\
\hline HHI & Herfindahl-Hirschman index. & $\begin{array}{l}\text { EU Banking Structures } \\
\text { reports }\end{array}$ & Positive/Negative \\
\hline$\Delta \mathrm{GDP}$ & $\begin{array}{l}\text { Annual percentage growth rate of GDP at market } \\
\text { prices based on constant local currency. }\end{array}$ & $\begin{array}{l}\text { World Bank Financial } \\
\text { Development Database }\end{array}$ & Positive \\
\hline GDP_PC & $\begin{array}{l}\text { Natural logarithm of yearly real GDP to the average } \\
\text { population of a specific year. }\end{array}$ & $\begin{array}{c}\text { Eurostat and World Bank } \\
\text { Financial Development } \\
\text { Database }\end{array}$ & Positive \\
\hline CRISIS & Equals 1 for the years $2008-2013,0$ otherwise. & Own computation & Negative \\
\hline
\end{tabular}


Table 2 - Summary statistics of the Z-score and its components by year

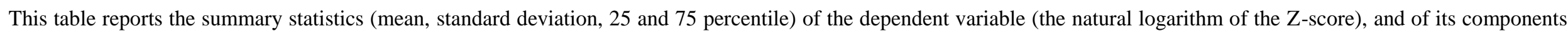

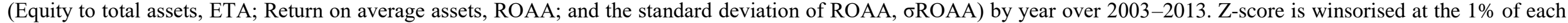
$\underline{\text { tail. }}$

\begin{tabular}{|c|c|c|c|c|c|c|c|c|}
\hline \multirow[b]{3}{*}{ Year } & \multirow{2}{*}{\multicolumn{2}{|c|}{ Z-score }} & \multicolumn{6}{|c|}{ Components of Z-score } \\
\hline & & & \multicolumn{2}{|c|}{ ETA } & \multicolumn{2}{|c|}{ ROAA } & \multicolumn{2}{|c|}{$\sigma \mathrm{ROAA}$} \\
\hline & $\begin{array}{c}\text { Mean } \\
\text { (Std. Dev.) }\end{array}$ & $25 \mathrm{p} .-75 \mathrm{p}$. & $\begin{array}{c}\text { Mean } \\
\text { (Std. Dev.) }\end{array}$ & 25 p. -75 p. & $\begin{array}{c}\text { Mean } \\
\text { (Std. Dev.) }\end{array}$ & 25 p. -75 p. & $\begin{array}{c}\text { Mean } \\
\text { (Std. Dev.) }\end{array}$ & $25 \mathrm{p} .-75 \mathrm{p}$. \\
\hline 2003 & $\begin{array}{c}4.449 \\
(1.410)\end{array}$ & $3.592-5.244$ & $\begin{array}{c}0.083 \\
(0.088)\end{array}$ & $0.046-0.081$ & $\begin{array}{c}0.004 \\
(0.008)\end{array}$ & $0.001-0.005$ & $\begin{array}{c}0.262 \\
(0.577)\end{array}$ & $0.028-0.221$ \\
\hline 2004 & $\begin{array}{c}4.589 \\
(1.450)\end{array}$ & $3.670-5.468$ & $\begin{array}{c}0.083 \\
(0.083)\end{array}$ & $0.048-0.084$ & $\begin{array}{c}0.004 \\
(0.008)\end{array}$ & $0.001-0.006$ & $\begin{array}{c}0.257 \\
(0.595)\end{array}$ & $0.024-0.199$ \\
\hline 2005 & $\begin{array}{c}4.586 \\
(1.574)\end{array}$ & $3.507-5.593$ & $\begin{array}{c}0.091 \\
(0.081)\end{array}$ & $0.053-0.102$ & $\begin{array}{c}0.006 \\
(0.008)\end{array}$ & $0.002-0.008$ & $\begin{array}{c}0.284 \\
(0.599)\end{array}$ & $0.021-0.258$ \\
\hline 2006 & $\begin{array}{c}4.580 \\
(1.603)\end{array}$ & $3.411-5.623$ & $\begin{array}{c}0.095 \\
(0.089)\end{array}$ & $0.055-0.103$ & $\begin{array}{c}0.006 \\
(0.007)\end{array}$ & $0.002-0.009$ & $\begin{array}{c}0.277 \\
(0.574)\end{array}$ & $0.021-0.282$ \\
\hline 2007 & $\begin{array}{c}4.435 \\
(1.457)\end{array}$ & $3.478-5.219$ & $\begin{array}{c}0.094 \\
(0.085)\end{array}$ & $0.055-0.103$ & $\begin{array}{c}0.005 \\
(0.007)\end{array}$ & $0.001-0.009$ & $\begin{array}{c}0.277 \\
(0.528)\end{array}$ & $0.035-0.294$ \\
\hline 2008 & $\begin{array}{l}4.230 \\
(1.455)\end{array}$ & $3.323-4.983$ & $\begin{array}{c}0.091 \\
(0.085)\end{array}$ & $0.053-0.100$ & $\begin{array}{c}0.003 \\
(0.008)\end{array}$ & $0.001-0.006$ & $\begin{array}{c}0.321 \\
(0.619)\end{array}$ & $0.046-0.300$ \\
\hline 2009 & $\begin{array}{c}4.176 \\
(1.484)\end{array}$ & $3.255-5.064$ & $\begin{array}{c}0.093 \\
(0.085)\end{array}$ & $0.055-0.102$ & $\begin{array}{c}0.002 \\
(0.008)\end{array}$ & $0.001-0.005$ & $\begin{array}{c}0.363 \\
(0.665)\end{array}$ & $0.042-0.379$ \\
\hline 2010 & $\begin{array}{c}4.265 \\
(1.513)\end{array}$ & $3.300-5.176$ & $\begin{array}{c}0.097 \\
(0.090)\end{array}$ & $0.058-0.102$ & $\begin{array}{c}0.002 \\
(0.008)\end{array}$ & $0.001-0.005$ & $\begin{array}{c}0.346 \\
(0.649)\end{array}$ & $0.041-0.346$ \\
\hline 2011 & $\begin{array}{c}4.577 \\
(1.643)\end{array}$ & $3.523-5.618$ & $\begin{array}{c}0.102 \\
(0.100)\end{array}$ & $0.062-0.104$ & $\begin{array}{c}0.002 \\
(0.009)\end{array}$ & $0.001-0.004$ & $\begin{array}{c}0.329 \\
(0.687)\end{array}$ & $0.029-0.274$ \\
\hline 2012 & $\begin{array}{c}4.679 \\
(1.702)\end{array}$ & $3.580-5.853$ & $\begin{array}{c}0.102 \\
(0.088)\end{array}$ & $0.067-0.107$ & $\begin{array}{c}0.002 \\
(0.009)\end{array}$ & $0.001-0.005$ & $\begin{array}{c}0.324 \\
(0.689)\end{array}$ & $0.023-0.276$ \\
\hline 2013 & $\begin{array}{c}4.791 \\
(1.761)\end{array}$ & $3.674-6.021$ & $\begin{array}{c}0.102 \\
(0.080)\end{array}$ & $0.071-0.108$ & $\begin{array}{c}0.002 \\
(0.008)\end{array}$ & $0.001-0.004$ & $\begin{array}{c}0.307 \\
(0.654)\end{array}$ & $0.020-0.260$ \\
\hline
\end{tabular}


Table 3 - Selected deposit insurance design features distribution across European countries

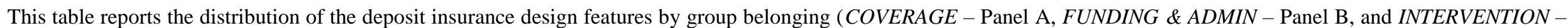

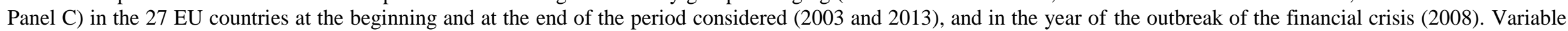
definitions are provided in Table 1 . All these characteristics are collected from the cross-country database on bank regulation and supervision compiled by the World Bank (2003, 2007, and 2012) and from the European Commission reports $(2004,2010$, and 2011). The symbol * denotes the presence of the blanket guarantee during the period 2008-2010.

Number of banks by country is indicated in brackets.

Panel A - COVERAGE

\begin{tabular}{|c|c|c|c|c|c|c|c|c|c|c|c|c|}
\hline \multirow[t]{2}{*}{ Country } & \multicolumn{3}{|c|}{$\begin{array}{l}\text { Level of Deposit Insurance Coverage } \\
\text { (in Euros) }\end{array}$} & \multicolumn{3}{|c|}{$\begin{array}{l}\text { Level of Deposit Insurance Coverage } \\
\text { to the real GDP per capita }\end{array}$} & \multicolumn{3}{|c|}{ HIGH_COV } & \multicolumn{3}{|c|}{ NO_COINS } \\
\hline & 2003 & 2008 & 2013 & 2003 & 2008 & 2013 & 2003 & 2008 & 2013 & 2003 & 2008 & 2013 \\
\hline Austria (289) & 20,000 & $50,000 *$ & 100,000 & 0.696 & 1.470 & 2.702 & 0 & 1 & 0 & 0 & 1 & 1 \\
\hline Belgium (48) & 20,000 & 100,000 & 100,000 & 0.714 & 3.086 & 2.898 & 0 & 1 & 0 & 0 & 1 & 1 \\
\hline Bulgaria (25) & 7,670 & 51,129 & 100,000 & 2.950 & 11.115 & 18.181 & 1 & 1 & 1 & 1 & 1 & 1 \\
\hline Cyprus (17) & 20,000 & 20,000 & 100,000 & 1.156 & 0.917 & 5.263 & 0 & 0 & 1 & 0 & 0 & 1 \\
\hline Czech Republic (26) & 25,000 & 50,000 & 100,000 & 2.777 & 3.378 & 7.042 & 1 & 1 & 1 & 0 & 1 & 1 \\
\hline Denmark (116) & 40,229 & $40,229 *$ & 100,000 & 1.102 & 0.939 & 2.252 & 0 & 0 & 0 & 1 & 1 & 1 \\
\hline Estonia (9) & 6,391 & 50,000 & 100,000 & 0.887 & 4.132 & 7.194 & 0 & 1 & 1 & 1 & 1 & 1 \\
\hline Finland (18) & 25,000 & 50,000 & 100,000 & 0.859 & 1.432 & 2.808 & 0 & 1 & 0 & 1 & 1 & 1 \\
\hline France (283) & 70,000 & 70,000 & 100,000 & 2.641 & 2.325 & 3.194 & 1 & 1 & 0 & 0 & 1 & 1 \\
\hline Germany $(1,870)$ & 20,000 & $20,000 *$ & 100,000 & 0.751 & 0.664 & 3.003 & 0 & 0 & 0 & 0 & 0 & 1 \\
\hline Greece (20) & 20,000 & $100,000 *$ & 100,000 & 1.190 & 4.807 & 6.060 & 1 & 1 & 1 & 1 & 1 & 1 \\
\hline Hungary (31) & 11,829 & $49,430 *$ & 100,000 & 1.460 & 4.707 & 10.101 & 1 & 1 & 1 & 0 & 1 & 1 \\
\hline Ireland (16) & 20,000 & $100,000 *$ & 100,000 & 0.542 & 2.493 & 2.808 & 0 & 1 & 0 & 0 & 1 & 1 \\
\hline Italy (674) & 103,291 & 103,291 & 100,000 & 4.303 & 3.927 & 3.906 & 1 & 1 & 1 & 1 & 1 & 1 \\
\hline Latvia (22) & 4,600 & 50,000 & 100,000 & 0.938 & 4.761 & 8.620 & 0 & 1 & 1 & 0 & 1 & 1 \\
\hline Lithuania (12) & 20,000 & 100,000 & 100,000 & 3.703 & 9.900 & 8.547 & 1 & 1 & 1 & 0 & 1 & 1 \\
\hline Luxembourg (95) & 20,000 & 20,000 & 100,000 & 0.333 & 0.261 & 1.199 & 0 & 0 & 0 & 1 & 1 & 1 \\
\hline Malta (9) & 20,000 & 20,000 & 100,000 & 1.724 & 1.369 & 5.813 & 1 & 0 & 1 & 0 & 0 & 1 \\
\hline Netherlands (38) & 20,000 & 100,000 & 100,000 & 0.662 & 2.762 & 2.785 & 0 & 1 & 0 & 1 & 1 & 1 \\
\hline Poland (48) & 22,500 & 50,000 & 100,000 & 4.245 & 5.263 & 9.900 & 1 & 1 & 1 & 0 & 1 & 1 \\
\hline Portugal (29) & 25,000 & 100,000 & 100,000 & 1.760 & 6.172 & 6.329 & 1 & 1 & 1 & 0 & 1 & 1 \\
\hline Romania (29) & 3,000 & 50,000 & 100,000 & 1.071 & 7.352 & 14.048 & 0 & 1 & 1 & 1 & 1 & 1 \\
\hline Slovakia (17) & 20,000 & $100,000 *$ & 100,000 & 3.174 & 1.680 & 7.518 & 1 & 1 & 1 & 0 & 1 & 1 \\
\hline Slovenia (18) & 18,500 & $22,000 *$ & 100,000 & 1.360 & 1.195 & 5.847 & 1 & 0 & 1 & 0 & 1 & 1 \\
\hline Spain (189) & 20,000 & 100,000 & 100,000 & 1.015 & 4.184 & 4.484 & 0 & 1 & 1 & 1 & 1 & 1 \\
\hline Sweden (103) & 27,533 & 50,000 & 100,000 & 0.849 & 1.385 & 2.283 & 0 & 0 & 0 & 1 & 1 & 1 \\
\hline United Kingdom (136) & 44,961 & 64,329 & 102,040 & 1.503 & 2.151 & 3.378 & 1 & 1 & 1 & 0 & 0 & 1 \\
\hline
\end{tabular}


Panel B - FUNDING \& ADMIN

\begin{tabular}{|c|c|c|c|c|c|c|c|c|c|c|c|c|}
\hline \multirow[b]{2}{*}{ Country } & \multicolumn{3}{|c|}{ GOV_FUND } & \multicolumn{3}{|c|}{ NO_EXANTE } & \multicolumn{3}{|c|}{ NO_RISKADJ } & \multicolumn{3}{|c|}{ NO_GOVADMIN } \\
\hline & 2003 & 2008 & 2013 & 2003 & 2008 & 2013 & 2003 & 2008 & 2013 & 2003 & 2008 & 2013 \\
\hline Austria & 0 & 0 & 0 & 1 & 1 & 1 & 1 & 1 & 1 & 0 & 0 & 0 \\
\hline Belgium & 0 & 0 & 0 & 0 & 0 & 0 & 0 & 0 & 0 & 0 & 1 & 1 \\
\hline Bulgaria & 0 & 0 & 0 & 0 & 0 & 0 & 1 & 1 & 1 & 1 & 1 & 1 \\
\hline Cyprus & 0 & 0 & 0 & 1 & 0 & 0 & 1 & 1 & 1 & 1 & 1 & 1 \\
\hline Czech Republic & 0 & 0 & 0 & 0 & 0 & 0 & 1 & 1 & 1 & 1 & 1 & 1 \\
\hline Denmark & 0 & 0 & 0 & 0 & 0 & 0 & 1 & 1 & 1 & 1 & 1 & 1 \\
\hline Estonia & 0 & 0 & 0 & 0 & 0 & 0 & 1 & 1 & 1 & 1 & 1 & 1 \\
\hline Finland & 0 & 0 & 0 & 0 & 0 & 0 & 0 & 0 & 0 & 0 & 0 & 0 \\
\hline France & 0 & 0 & 0 & 0 & 0 & 0 & 0 & 0 & 0 & 0 & 0 & 0 \\
\hline Germany & 0 & 0 & 0 & 0 & 0 & 0 & 0 & 0 & 0 & 1 & 1 & 1 \\
\hline Greece & 0 & 0 & 0 & 0 & 0 & 0 & 1 & 1 & 0 & 1 & 1 & 1 \\
\hline Hungary & 0 & 0 & 0 & 0 & 0 & 0 & 0 & 0 & 0 & 1 & 1 & 1 \\
\hline Ireland & 0 & 0 & 0 & 0 & 0 & 0 & 1 & 1 & 1 & 1 & 1 & 1 \\
\hline Italy & 0 & 0 & 0 & 1 & 1 & 1 & 0 & 0 & 0 & 0 & 0 & 0 \\
\hline Latvia & 1 & 1 & 1 & 0 & 0 & 0 & 1 & 1 & 0 & 1 & 1 & 1 \\
\hline Lithuania & 1 & 0 & 0 & 0 & 0 & 0 & 1 & 1 & 1 & 1 & 1 & 1 \\
\hline Luxembourg & 0 & 0 & 0 & 1 & 1 & 1 & 1 & 1 & 1 & 1 & 0 & 0 \\
\hline Malta & 0 & 0 & 0 & 1 & 0 & 0 & 1 & 1 & 1 & 1 & 1 & 1 \\
\hline Netherlands & 0 & 0 & 1 & 1 & 1 & 0 & 1 & 1 & 0 & 1 & 1 & 1 \\
\hline Poland & 0 & 0 & 0 & 1 & 0 & 0 & 1 & 1 & 1 & 1 & 1 & 1 \\
\hline Portugal & 0 & 0 & 0 & 0 & 0 & 0 & 0 & 0 & 0 & 1 & 1 & 1 \\
\hline Romania & 0 & 0 & 0 & 0 & 0 & 0 & 1 & 0 & 0 & 1 & 1 & 1 \\
\hline Slovakia & 0 & 0 & 0 & 1 & 0 & 0 & 1 & 1 & 1 & 1 & 1 & 1 \\
\hline Slovenia & 0 & 0 & 0 & 1 & 1 & 1 & 1 & 1 & 1 & 1 & 0 & 0 \\
\hline Spain & 0 & 0 & 0 & 0 & 0 & 0 & 1 & 1 & 1 & 1 & 1 & 1 \\
\hline Sweden & 1 & 0 & 0 & 0 & 0 & 0 & 0 & 0 & 0 & 1 & 1 & 1 \\
\hline United Kingdom & 0 & 0 & 0 & 1 & 1 & 1 & 1 & 1 & 1 & 1 & 1 & 1 \\
\hline
\end{tabular}


Panel C - INTERVENTION

\begin{tabular}{|c|c|c|c|c|c|c|c|c|c|}
\hline \multirow[b]{2}{*}{ Country } & \multicolumn{3}{|c|}{ NO_INTERV } & \multicolumn{3}{|c|}{ NO_CANCEL } & \multicolumn{3}{|c|}{ NO_LEGALPWR } \\
\hline & 2003 & 2008 & 2013 & 2003 & 2008 & 2013 & 2003 & 2008 & 2013 \\
\hline Austria & 1 & 1 & 1 & 0 & 1 & 1 & 1 & 1 & 1 \\
\hline Belgium & 1 & 0 & 0 & 1 & 1 & 1 & 0 & 0 & 0 \\
\hline Bulgaria & 1 & 1 & 1 & 1 & 1 & 1 & 1 & 1 & 1 \\
\hline Cyprus & 1 & 1 & 1 & 0 & 1 & 1 & 1 & 1 & 1 \\
\hline Czech Republic & 1 & 1 & 1 & 1 & 1 & 1 & 1 & 1 & 1 \\
\hline Denmark & 1 & 1 & 1 & 0 & 1 & 1 & 1 & 1 & 1 \\
\hline Estonia & 1 & 1 & 1 & 1 & 1 & 1 & 1 & 1 & 1 \\
\hline Finland & 1 & 1 & 1 & 0 & 1 & 1 & 0 & 1 & 1 \\
\hline France & 1 & 1 & 1 & 0 & 1 & 1 & 0 & 0 & 0 \\
\hline Germany & 1 & 1 & 1 & 1 & 0 & 0 & 0 & 1 & 1 \\
\hline Greece & 1 & 1 & 1 & 0 & 0 & 0 & 1 & 1 & 1 \\
\hline Hungary & 0 & 1 & 1 & 0 & 0 & 0 & 1 & 1 & 1 \\
\hline Ireland & 1 & 0 & 0 & 0 & 0 & 0 & 1 & 0 & 0 \\
\hline Italy & 0 & 1 & 1 & 0 & 1 & 1 & 1 & 1 & 1 \\
\hline Latvia & 1 & 1 & 1 & 1 & 0 & 0 & 0 & 0 & 0 \\
\hline Lithuania & 1 & 1 & 1 & 0 & 1 & 1 & 1 & 1 & 1 \\
\hline Luxembourg & 1 & 1 & 1 & 0 & 0 & 0 & 1 & 0 & 0 \\
\hline Malta & 1 & 1 & 1 & 1 & 1 & 1 & 0 & 0 & 0 \\
\hline Netherlands & 1 & 1 & 1 & 1 & 1 & 1 & 0 & 1 & 1 \\
\hline Poland & 1 & 1 & 1 & 1 & 1 & 1 & 1 & 1 & 1 \\
\hline Portugal & 1 & 1 & 1 & 1 & 1 & 1 & 1 & 1 & 1 \\
\hline Romania & 1 & 1 & 1 & 1 & 1 & 1 & 1 & 1 & 1 \\
\hline Slovakia & 0 & 1 & 1 & 1 & 1 & 1 & 0 & 1 & 1 \\
\hline Slovenia & 0 & 0 & 0 & 1 & 1 & 1 & 0 & 0 & 0 \\
\hline Spain & 1 & 1 & 1 & 1 & 1 & 1 & 0 & 0 & 0 \\
\hline Sweden & 1 & 1 & 1 & 0 & 1 & 1 & 1 & 1 & 1 \\
\hline United Kingdom & 1 & 1 & 1 & 1 & 0 & 0 & 0 & 1 & 1 \\
\hline
\end{tabular}


Table 4 - Summary statistics of the control variables in the pre-crisis and crisis periods

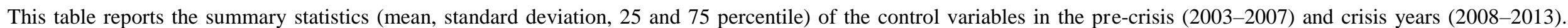

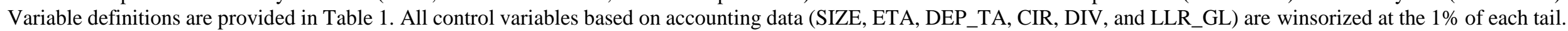
$* * *, * *$, and $*$ denote statistical significance at $1 \%, 5 \%$ and $10 \%$ levels for test of differences in means between pre-crisis (I) and crisis period (II).

\begin{tabular}{|c|c|c|c|c|c|}
\hline \multirow[t]{2}{*}{ Variables } & \multicolumn{2}{|c|}{$\begin{array}{c}\text { Pre-crisis period } \\
\text { (I) } \\
\end{array}$} & \multicolumn{2}{|c|}{$\begin{array}{c}\text { Crisis period } \\
\text { (II) }\end{array}$} & \multirow{2}{*}{$\begin{array}{c}\text { Difference } \\
\text { in means } \\
(\mathrm{I})-(\mathrm{II})\end{array}$} \\
\hline & $\begin{array}{c}\text { Mean } \\
\text { (Std. Dev.) }\end{array}$ & 25 p.- 75 p. & $\begin{array}{c}\text { Mean } \\
\text { (Std. Dev.) }\end{array}$ & 25 p.- 75 p. & \\
\hline SIZE & $\begin{array}{c}6.448 \\
(1.563)\end{array}$ & $5.479-7.309$ & $\begin{array}{c}6.664 \\
(1.803)\end{array}$ & $5.436-7.616$ & $-0.215 * * *$ \\
\hline ETA & $\begin{array}{c}0.083 \\
(0.075)\end{array}$ & $0.050-0.088$ & $\begin{array}{c}0.094 \\
(0.078)\end{array}$ & $0.060-0.103$ & $-0.011 * * *$ \\
\hline DEP_TA & $\begin{array}{c}0.659 \\
(0.1919\end{array}$ & $0.593-0.788$ & $\begin{array}{c}0.643 \\
(0.197)\end{array}$ & $0.533-0.786$ & $0.016 * * *$ \\
\hline CIR & $\begin{array}{c}0.674 \\
(0.156)\end{array}$ & $0.601-0.750$ & $\begin{array}{c}0.677 \\
(0.169)\end{array}$ & $0.597-0.750$ & -0.002 \\
\hline DIV & $\begin{array}{c}0.296 \\
(0.159)\end{array}$ & $0.215-0.345$ & $\begin{array}{c}0.291 \\
(0.164)\end{array}$ & $0.214-0.333$ & $0.004 * *$ \\
\hline LLR_GL & $\begin{array}{c}0.007 \\
(0.0001)\end{array}$ & $0-0.002$ & $\begin{array}{c}0.017 \\
(0.0001)\end{array}$ & $0-0.024$ & $-0.009 * * *$ \\
\hline HHI & $\begin{array}{c}0.040 \\
(0.040)\end{array}$ & $0.017-0.053$ & $\begin{array}{c}0.045 \\
(0.036)\end{array}$ & $0.0298-0.046$ & $-0.004 * * *$ \\
\hline$\Delta \mathrm{GDP}$ & $\begin{array}{c}0.023 \\
(0.018)\end{array}$ & $0.008-0.036$ & $\begin{array}{c}0.001 \\
(0.029)\end{array}$ & $-0.011-0.017$ & $0.022 * * *$ \\
\hline GDP_PC & $\begin{array}{l}10.190 \\
(0.386) \\
\end{array}$ & $10.188-10.292$ & $\begin{array}{l}10.271 \\
(0.323) \\
\end{array}$ & $10.165-10.392$ & $-0.080 * * *$ \\
\hline
\end{tabular}


Table 5 - Panel estimation results with quadratic transformation of deposit coverage for different sub-samples

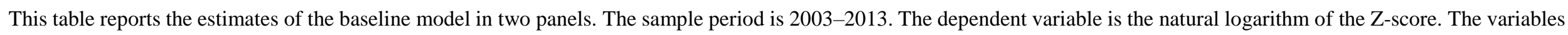
of interest are: COV RATIO, its square COV_RATIO2, and the two aggregate variables FUNDING \& ADMIN, and INTERVENTION. All our target variables are interacted with

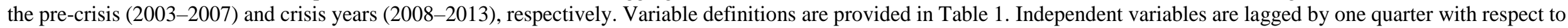

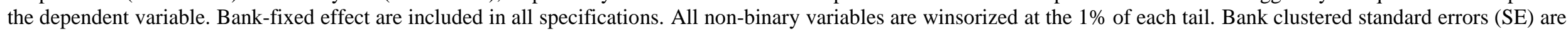
reported in parentheses. The superscripts $* * *, * *$, and $*$ denote coefficients statistically different from zero at the $1 \%, 5 \%$, and $10 \%$ levels, respectively, in two-tailed tests.

Panel A reports the baseline model for 'All banks' and for the following sub-samples: commercial versus cooperative and savings banks; the smallest (bottom quartile by SIZE) versus the biggest banks (top quartile by SIZE); banks with the lowest reliance on customer deposits (bottom quartile by DEP_TA) versus those with the highest dependency from customer deposits (top quartile by DEP TA). The figures in brackets in the headline row indicate the number of banks.

Panel B reports the results for no-GIIPS countries (different from Greece, Ireland, Italy, Portugal, and Spain) from the sample, orientation of the financial system (bottom quartile by the ratio of domestic credit provided by banking sector to GDP vs top quartile) and the supervisory power of the authority (below vs above the sample mean). 
$\underline{\text { Panel A - Types of banks }}$

\begin{tabular}{|c|c|c|c|c|c|c|c|}
\hline Variables & $\begin{array}{l}\text { All banks } \\
(4,187 \text { obs })\end{array}$ & $\begin{array}{c}\text { Commercial banks } \\
(1,215 \text { obs })\end{array}$ & $\begin{array}{c}\text { Cooperative \& Savings } \\
\text { banks } \\
(2,972 \text { obs })\end{array}$ & Small banks & Large banks & $\begin{array}{c}\text { Banks } \\
\text { with the lowest } \\
\text { dependency on } \\
\text { customer deposits }\end{array}$ & $\begin{array}{c}\text { Banks } \\
\text { with the highest } \\
\text { dependency on } \\
\text { customer deposits }\end{array}$ \\
\hline COV_RATIO (-1)*pre-crisis & $0.226 * * *$ & $\begin{array}{c}0.212 * * * \\
(0.075)\end{array}$ & $\begin{array}{c}0.689 * * * \\
(0211)\end{array}$ & $\begin{array}{l}-0.446 \\
(0.278)\end{array}$ & $\begin{array}{c}0.418 * * * * \\
(0.089)\end{array}$ & $0.279 * * *$ & $\begin{array}{c}-0.151 \\
(0.121)\end{array}$ \\
\hline COV_RATIO2 (-1)*pre-crisis & $\begin{array}{l}-0.053 \\
(0.057)\end{array}$ & $\begin{array}{c}-0.173 * * \\
(0.072)\end{array}$ & $\begin{array}{c}-0.582 * * * \\
(0.206)\end{array}$ & $\begin{array}{c}0.318 \\
(0.255)\end{array}$ & $\begin{array}{c}0.012 \\
(0.085)\end{array}$ & $\begin{array}{c}-0.191 * * \\
(0.093)\end{array}$ & $\begin{array}{l}-0.086 \\
(0.122)\end{array}$ \\
\hline COV_RATIO $(-1) *$ crisis & $\begin{array}{c}0.323 * * * \\
(0.032)\end{array}$ & $\begin{array}{c}0.353 * * * \\
(0.057)\end{array}$ & $\begin{array}{c}0.191 * * * \\
(0.048)\end{array}$ & $\begin{array}{c}0.116 \\
(0.081)\end{array}$ & $\begin{array}{c}0.439^{* * * *} \\
(0.062)\end{array}$ & $\begin{array}{c}0.338 * * * \\
(0.075)\end{array}$ & $\begin{array}{c}0.231 * * * \\
(0.060)\end{array}$ \\
\hline COV_RATIO2 (-1)*crisis & $\begin{array}{c}-0.126 * * * \\
(0.027)\end{array}$ & $\begin{array}{c}-0.122 * * * \\
(0.034)\end{array}$ & $\begin{array}{l}-0.087^{*} \\
(0.050)\end{array}$ & $\begin{array}{l}-0.101 \\
(0.084)\end{array}$ & $\begin{array}{c}-0.126^{* * * *} \\
(0.044)\end{array}$ & $\begin{array}{c}-0.163 * * * \\
(0.052)\end{array}$ & $\begin{array}{c}-0.115^{* * *} \\
(0.048)\end{array}$ \\
\hline FUNDING \& ADMIN (-1)*pre-crisis & $\begin{array}{l}-0.002 \\
(0.060)\end{array}$ & $\begin{array}{l}-0.050 \\
(0.080)\end{array}$ & $\begin{array}{c}-0.220^{* *} \\
(0.103)\end{array}$ & $\begin{array}{l}-0.092 \\
(0.122)\end{array}$ & $\begin{array}{c}0.147 \\
(0.099)\end{array}$ & $\begin{array}{l}-0.228 \\
(0.139)\end{array}$ & $\begin{array}{l}-0.115 \\
(0.095)\end{array}$ \\
\hline FUNDING \& ADMIN $(-1)^{*}$ crisis & $\begin{array}{c}-0.200 * * * * \\
(0.063)\end{array}$ & $\begin{array}{l}-0.157^{*} \\
(0.083)\end{array}$ & $\begin{array}{c}-0.398 * * * \\
(0.108)\end{array}$ & $\begin{array}{c}-0.360^{* * * *} \\
(0.129)\end{array}$ & $\begin{array}{l}-0.082 \\
(0.106)\end{array}$ & $\begin{array}{c}-0.348 * * \\
(0.145)\end{array}$ & $\begin{array}{c}-0.290 * * * * \\
(0.101)\end{array}$ \\
\hline INTERVENTION (-1)*pre-crisis & $\begin{array}{c}-0.181 * * * \\
(0.029)\end{array}$ & $\begin{array}{l}-0.063 \\
(0.053)\end{array}$ & $\begin{array}{c}-0.144 * * * \\
(0.041)\end{array}$ & $\begin{array}{c}-0.411^{* * * *} \\
(0.077)\end{array}$ & $\begin{array}{l}-0.046 \\
(0.058)\end{array}$ & $\begin{array}{l}-0.038 \\
(0.067)\end{array}$ & $\begin{array}{c}-0.139^{* *} \\
(0.061)\end{array}$ \\
\hline INTERVENTION $(-1)^{*}$ crisis & $\begin{array}{c}-0.153 * * * \\
(0.030)\end{array}$ & $\begin{array}{c}0.055 \\
(0.057)\end{array}$ & $\begin{array}{c}-0.220 * * * \\
(0.036)\end{array}$ & $\begin{array}{c}-0.324 * * * \\
(0.069)\end{array}$ & $\begin{array}{l}-0.069 \\
(0.058)\end{array}$ & $\begin{array}{l}0.149^{*} \\
(0.077)\end{array}$ & $\begin{array}{c}-0.199 * * * \\
(0.060)\end{array}$ \\
\hline SIZE (-1) & $\begin{array}{c}0.128^{* * *} \\
(0.060)\end{array}$ & $\begin{array}{c}0.178 * * * \\
(0.069)\end{array}$ & $\begin{array}{c}0.029 \\
(0.105)\end{array}$ & $\begin{array}{c}0.236 \\
(0.147)\end{array}$ & $\begin{array}{c}0.137 \\
(0.095)\end{array}$ & $\begin{array}{c}0.303 * * * \\
(0.081)\end{array}$ & $\begin{array}{c}0.282 \\
(0.176)\end{array}$ \\
\hline $\operatorname{ETA}(-1)$ & $\begin{array}{c}2.873 * * * * \\
(0.436)\end{array}$ & $\begin{array}{c}1.995 * * * \\
(0.460)\end{array}$ & $\begin{array}{c}5.886 * * * \\
(0.997)\end{array}$ & $\begin{array}{l}1.783 * * \\
(0.794)\end{array}$ & $\begin{array}{c}6.642 * * * \\
(1.260)\end{array}$ & $\begin{array}{c}1.679 * * * \\
(0.511)\end{array}$ & $\begin{array}{c}4.256 * * * \\
(1.520)\end{array}$ \\
\hline CIR $(-1)$ & $\begin{array}{c}-0.595 * * * \\
(0.083)\end{array}$ & $\begin{array}{c}-0.661 * * * \\
(0.107)\end{array}$ & $\begin{array}{c}-0.335^{* *} \\
(0.132)\end{array}$ & $\begin{array}{c}-0.600^{* * * *} \\
(0.145)\end{array}$ & $\begin{array}{c}-0.855^{* * * *} \\
(0.152)\end{array}$ & $\begin{array}{c}-0.390 * * * \\
(0.126)\end{array}$ & $\begin{array}{c}-0.675^{* * * *} \\
(0.180)\end{array}$ \\
\hline DIV $(-1)$ & $\begin{array}{l}-0.038 \\
(0.103)\end{array}$ & $\begin{array}{l}-0.100 \\
(0.128)\end{array}$ & $\begin{array}{c}0.005 \\
(0.168)\end{array}$ & $\begin{array}{c}-0.619 * * * \\
(0.212)\end{array}$ & $\begin{array}{l}-0.211 \\
(0.165)\end{array}$ & $\begin{array}{c}0.161 \\
(0.135)\end{array}$ & $\begin{array}{c}-0.661 * * * \\
(0.238)\end{array}$ \\
\hline LLR_GL (-1) & $\begin{array}{c}-1.529 * * \\
(0.710)\end{array}$ & $\begin{array}{c}-3.629 * * * \\
(0.970)\end{array}$ & $\begin{array}{c}1.230 \\
(1.110)\end{array}$ & $\begin{array}{c}0.482 \\
(1.413)\end{array}$ & $\begin{array}{c}-4.678^{* * * *} \\
(1.343)\end{array}$ & $\begin{array}{c}-3.137^{* *} \\
(1.278)\end{array}$ & $\begin{array}{c}1.302 \\
(1.924)\end{array}$ \\
\hline HHI (-1) & $\begin{array}{c}5.980 * * * \\
(1.168)\end{array}$ & $\begin{array}{l}-1.348 \\
(1.426)\end{array}$ & $\begin{array}{c}12.522 * * * \\
(2.209)\end{array}$ & $\begin{array}{c}2.235 \\
(3.770)\end{array}$ & $\begin{array}{c}3.741 * * \\
(1.553)\end{array}$ & $\begin{array}{c}4.760^{* *} \\
(2.163)\end{array}$ & $\begin{array}{c}0.114 \\
(1.908)\end{array}$ \\
\hline$\Delta \mathrm{GDP}(-1)$ & $2.524 * * *$ & $2.774 * * *$ & $1.198^{* * * *}$ & $2.295 * * *$ & $2.943 * * *$ & $3.412 * * *$ & $2.318^{* * *}$ \\
\hline GDP_PC (-1) & $\begin{array}{c}(0.265) \\
0.971 * * * \\
(0.188)\end{array}$ & $\begin{array}{l}(0.454) \\
-0.050 \\
(0.219)\end{array}$ & $\begin{array}{c}(0.387) \\
2.276^{* * *} \\
(0.340)\end{array}$ & $\begin{array}{c}(0.613) \\
0.667 \\
(0.420)\end{array}$ & $\begin{array}{c}(0.503) \\
1.306 * * * \\
(0.324)\end{array}$ & $\begin{array}{c}(0.540) \\
-0.195 \\
(0.358)\end{array}$ & $\begin{array}{l}(0.526) \\
0.745^{*} \\
(0.381)\end{array}$ \\
\hline CRISIS & $\begin{array}{l}-0.155 \\
(0.100)\end{array}$ & $\begin{array}{c}-0.552 * * * \\
(0.165)\end{array}$ & $\begin{array}{l}-0.248^{*} \\
(0.132)\end{array}$ & $\begin{array}{l}-0.062 \\
(0.253)\end{array}$ & $\begin{array}{l}-0.135 \\
(0.177)\end{array}$ & $\begin{array}{c}-0.687 * * * \\
(0.212)\end{array}$ & $\begin{array}{l}0.046 \\
(0.220)\end{array}$ \\
\hline Bank FE & Yes & Yes & Yes & Yes & Yes & Yes & Yes \\
\hline Country FE & No & No & No & No & No & No & No \\
\hline Cluster SE Bank & Yes & Yes & Yes & Yes & Yes & Yes & Yes \\
\hline N. of obs. & 27,584 & 6,780 & 20,804 & 6,004 & 7,012 & 6,382 & 6,862 \\
\hline R-squared & 0.062 & 0.073 & 0.072 & 0.054 & 0.117 & 0.058 & 0.050 \\
\hline
\end{tabular}


$\underline{\text { Panel B - Operating environment }}$

\begin{tabular}{|c|c|c|c|c|c|}
\hline Variables & No-GIIPS countries & $\begin{array}{c}\text { Market-oriented financial } \\
\text { systems }\end{array}$ & $\begin{array}{c}\text { Bank-oriented financial } \\
\text { systems }\end{array}$ & Weak supervisory power & Strong supervisory power \\
\hline COV_RATIO (-1)*pre-crisis & $\begin{array}{c}0.271 * * * \\
(0.063)\end{array}$ & $\begin{array}{l}-0.042 \\
(0.303)\end{array}$ & $\begin{array}{c}0.142 \\
(0.226)\end{array}$ & $\begin{array}{c}0.860 * * * \\
(0.185)\end{array}$ & $\begin{array}{c}0.120 \\
(0.076)\end{array}$ \\
\hline COV_RATIO2 $(-1) *$ pre-crisis & $\begin{array}{c}0.096 \\
(0.078)\end{array}$ & $\begin{array}{l}-0.227 \\
(0.246)\end{array}$ & $\begin{array}{c}-0.599 * * \\
(0.238)\end{array}$ & $\begin{array}{c}-0.501 * * * \\
(0.177)\end{array}$ & $\begin{array}{c}-0.234 * * * * \\
(0.076)\end{array}$ \\
\hline COV_RATIO $(-1) *$ crisis & $\begin{array}{c}0.297 * * * * \\
(0.033)\end{array}$ & $\begin{array}{l}-0.075 \\
(0.167)\end{array}$ & $\begin{array}{c}0.333 * * * * \\
(0.064)\end{array}$ & $\begin{array}{c}0.160^{* * * *} \\
(0.054)\end{array}$ & $\begin{array}{c}0.159^{* * * *} \\
(0.056)\end{array}$ \\
\hline COV_RATIO2 (-1)*crisis & $\begin{array}{c}-0.073^{* * *} \\
(0.030)\end{array}$ & $\begin{array}{l}-0.023 \\
(0.073)\end{array}$ & $\begin{array}{r}-0.082^{*} \\
(0.047)\end{array}$ & $\begin{array}{c}0.184 * * * \\
(0.070)\end{array}$ & $\begin{array}{c}-0.090^{* * * *} \\
(0.033)\end{array}$ \\
\hline FUNDING \& ADMIN (-1)*pre-crisis & $\begin{array}{l}-0.037 \\
(0.061)\end{array}$ & $\begin{array}{l}-0.076 \\
(0.105)\end{array}$ & $\begin{array}{c}-0.473 * * \\
(0.239)\end{array}$ & $\begin{array}{c}0.064 \\
(0.092)\end{array}$ & $\begin{array}{l}-0.053 \\
(0.083)\end{array}$ \\
\hline FUNDING \& ADMIN (-1)*crisis & $\begin{array}{c}-0.224 * * * \\
(0.065)\end{array}$ & $\begin{array}{c}-0.364 * * * \\
(0.126)\end{array}$ & $\begin{array}{l}-0.292 \\
(0.205)\end{array}$ & $\begin{array}{c}0.066 \\
(0.092)\end{array}$ & $\begin{array}{l}-0.046 \\
(0.086)\end{array}$ \\
\hline INTERVENTION (-1)*pre-crisis & $\begin{array}{c}-0.133 * * * \\
(0.030)\end{array}$ & $\begin{array}{c}-0.156^{* * *} \\
(0.061)\end{array}$ & $\begin{array}{l}-0.273 \\
(0.184)\end{array}$ & $\begin{array}{l}-0.053 \\
(0.038)\end{array}$ & $\begin{array}{l}-0.031 \\
(0.054)\end{array}$ \\
\hline INTERVENTION (-1)*crisis & $\begin{array}{c}-0.173^{* * * *} \\
(0.030)\end{array}$ & $\begin{array}{l}-0.148 \\
(0.101)\end{array}$ & $\begin{array}{c}0.211^{* * * *} \\
(0.082)\end{array}$ & $\begin{array}{c}-0.168 * * * \\
(0.033)\end{array}$ & $\begin{array}{c}0.056 \\
(0.056)\end{array}$ \\
\hline SIZE (-1) & $\begin{array}{c}0.077 \\
(0.067)\end{array}$ & $\begin{array}{c}0.264 * * \\
(0.106)\end{array}$ & $\begin{array}{c}0.283^{* * * *} \\
(0.100)\end{array}$ & $\begin{array}{c}-0.208^{* *} \\
(0.102)\end{array}$ & $\begin{array}{c}0.314 * * * \\
(0.086)\end{array}$ \\
\hline ETA $(-1)$ & $\begin{array}{c}2.617 * * * \\
(0.464)\end{array}$ & $\begin{array}{c}2.888 * * * \\
(0.943)\end{array}$ & $\begin{array}{c}2.740 * * * \\
(0.755)\end{array}$ & $\begin{array}{l}1.551^{* * *} * \\
(0.585)\end{array}$ & $\begin{array}{l}2.132 * * * \\
(0.618)\end{array}$ \\
\hline DEP_TA (-1) & $\begin{array}{c}0.764 * * * \\
(0.212)\end{array}$ & $\begin{array}{l}0.607^{*} \\
(0.359)\end{array}$ & $\begin{array}{c}0.163 \\
(0.280)\end{array}$ & $\begin{array}{c}0.678 * * \\
(0.306)\end{array}$ & $\begin{array}{c}0.331 \\
(0.231)\end{array}$ \\
\hline CIR (-1) & $\begin{array}{c}-0.545^{* * *} \\
(0.095)\end{array}$ & $\begin{array}{c}-0.692 * * * \\
(0.149)\end{array}$ & $\begin{array}{c}-0.535^{* * * *} \\
(0.139)\end{array}$ & $\begin{array}{c}-0.438 * * * \\
(0.126)\end{array}$ & $\begin{array}{c}-0.576^{* * * *} \\
(0.118)\end{array}$ \\
\hline $\operatorname{DIV}(-1)$ & $\begin{array}{l}-0.083 \\
(0.120)\end{array}$ & $\begin{array}{l}-0.186 \\
(0.253)\end{array}$ & $\begin{array}{l}-0.041 \\
(0.150)\end{array}$ & $\begin{array}{l}-0.221 \\
(0.150)\end{array}$ & $\begin{array}{l}-0.034 \\
(0.150)\end{array}$ \\
\hline LLR_GL (-1) & $\begin{array}{l}-1.309 \\
(0.861)\end{array}$ & $\begin{array}{l}-4.112 * * * \\
(1.124)\end{array}$ & $\begin{array}{l}-0.076 \\
(0.959)\end{array}$ & $\begin{array}{l}0.449 \\
(1.088)\end{array}$ & $\begin{array}{c}-3.182 * * * \\
(1.074)\end{array}$ \\
\hline HHI (-1) & $\begin{array}{l}5.962 * * * \\
(1.219)\end{array}$ & $\begin{array}{l}-0.341 \\
(1.621)\end{array}$ & $\begin{array}{l}-5.147 \\
(3.156)\end{array}$ & $\begin{array}{l}-4.546 \\
(2.810)\end{array}$ & $\begin{array}{l}-1.638 \\
(1.454)\end{array}$ \\
\hline$\Delta \mathrm{GDP}(-1)$ & $\begin{array}{c}1.639 * * * \\
(0.310)\end{array}$ & $\begin{array}{l}0.391 \\
(0.624)\end{array}$ & $\begin{array}{c}4.189 * * * \\
(0.480)\end{array}$ & $\begin{array}{l}-0.615 \\
(0.557)\end{array}$ & $\begin{array}{l}1.668 * * * \\
(0.508)\end{array}$ \\
\hline GDP_PC (-1) & $\begin{array}{c}0.985 * * * \\
(0.207)\end{array}$ & $\begin{array}{l}0.490^{*} \\
(0.292)\end{array}$ & $\begin{array}{c}0.425 \\
(0.363)\end{array}$ & $\begin{array}{c}3.089^{* * * *} \\
(0.322)\end{array}$ & $\begin{array}{l}-0.444 * \\
(0.262)\end{array}$ \\
\hline CRISIS & $\begin{array}{l}-0.002 \\
(0.104)\end{array}$ & $\begin{array}{l}-0.218 \\
(0.303)\end{array}$ & $\begin{array}{c}-2.117 * * * \\
(0.597)\end{array}$ & $\begin{array}{c}-0.306^{* * *} \\
(0.124)\end{array}$ & $\begin{array}{c}-0.783 * * * \\
(0.230)\end{array}$ \\
\hline Bank FE & Yes & Yes & Yes & Yes & Yes \\
\hline Cluster SE Bank & Yes & Yes & Yes & Yes & Yes \\
\hline N. of obs. & 22,561 & 5,763 & 5,621 & 20,138 & 7,446 \\
\hline R-squared & 0.065 & 0.065 & 0.089 & 0.076 & 0.079 \\
\hline
\end{tabular}


Table 6 - The relationship between deposit insurance features and stability

This table reports estimates of bank fixed-effect (FE) regressions for the full sample over the period 2003-2013. Model (I) shows estimates for our variables of interest considered at aggregate level (COVERAGE, FUNDING \& ADMIN, and, INTERVENTION), plus the control variables. Models (II), (III), and (IV) show estimates obtained by splitting COV_SUM, FUNDING \& ADMIN, and, INTERVENTION into their components, plus the control variables. All our variables of interest are interacted with the pre-crisis (2003-2007) and crisis years (2008-2013), respectively. The dependent variable is the natural logarithm of the Z-score. The control variables include: SIZE, ETA, DEP_TA, CIR, DIV, LLR_GL, HHI, $\triangle$ GDP, and GDP_PC. Variable definitions are provided in Table 1. Independent variables are lagged by one year with respect to the dependent variable. All non-binary variables are winsorized at the $1 \%$ of each tail. Bank clustered standard errors (SE) are reported in parentheses. The columns "Test" report the level of significance of the difference of each DIS feature's coefficients in the two periods under investigation. The superscripts $* * *$, **, and * denote coefficients statistically different from zero at the $1 \%, 5 \%$, and $10 \%$ levels, respectively, in two-tailed tests.

\begin{tabular}{|c|c|c|c|c|c|c|c|c|}
\hline Variables & (I) & Test & (II) & Test & (III) & Test & (IV) & Test \\
\hline COVERAGE (-1)*pre-crisi & $\begin{array}{c}0.152 * * * \\
(0.031)\end{array}$ & & & & $\begin{array}{c}0.177 * * * \\
(0.035)\end{array}$ & & $\begin{array}{c}0.037 \\
(0.031)\end{array}$ & \\
\hline COVERAGE $(-1) *$ crisis & $\begin{array}{c}0.101 * * * \\
(0.025)\end{array}$ & $* *$ & & & $\begin{array}{c}0.073 * * * \\
(0.024)\end{array}$ & $* * *$ & $\begin{array}{c}0.083 * * * \\
(0.025)\end{array}$ & \\
\hline HIGH_COV $(-1)^{*}$ pre-crisis & & & $\begin{array}{l}-0.075 \\
(0.056)\end{array}$ & & & & & \\
\hline HIGH_COV $(-1)^{*}$ crisis & & & $\begin{array}{c}-0.277 * * * \\
(0.036)\end{array}$ & **** & & & & \\
\hline NO_COINS $(-1) *$ pre-crisis & & & $\begin{array}{c}0.183 * * * \\
(0.046)\end{array}$ & & & & & \\
\hline NO_COINS $(-1)^{*}$ crisis & & & $\begin{array}{c}0.306^{* * * *} \\
(0.032)\end{array}$ & $* * *$ & & & & \\
\hline FUNDING \& ADMIN (-1)*pre-crisis & $\begin{array}{l}-0.018 \\
(0.061)\end{array}$ & & $\begin{array}{l}-0.028 \\
(0.059)\end{array}$ & & & & $\begin{array}{l}-0.060 \\
(0.061)\end{array}$ & \\
\hline FUNDING \& ADMIN (-1)*crisis & $\begin{array}{c}-0.187 * * * \\
(0.064)\end{array}$ & $* * *$ & $\begin{array}{c}-0.172 * * * \\
(0.063)\end{array}$ & $* * *$ & & & $\begin{array}{l}-0.212 * * * \\
(0.064)\end{array}$ & *** \\
\hline GOV_FUND $(-1) *$ pre-crisis & & & & & $\begin{array}{c}0.970 * * * \\
(0.129)\end{array}$ & & & \\
\hline GOV_FUND $(-1)^{*}$ crisis & & & & & $\begin{array}{l}-0.332 \\
(0.212)\end{array}$ & $* * *$ & & \\
\hline NO_EXANTE $(-1) *$ pre-crisis & & & & & $\begin{array}{c}-0.339 * * * \\
(0.130)\end{array}$ & & & \\
\hline NO_EXANTE $(-1) *$ crisis & & & & & $\begin{array}{l}-0.145 \\
(0.133)\end{array}$ & $* * *$ & & \\
\hline NO_RISKADJ (-1)*pre-crisis & & & & & $\begin{array}{l}-0.031 \\
(0.094)\end{array}$ & & & \\
\hline NO_RISKADJ $(-1)^{*}$ crisis & & & & & $\begin{array}{c}-0.563^{* * *} \\
(0.091)\end{array}$ & $* * *$ & & \\
\hline GOV_ADMIN (-1)*pre-crisis & & & & & $\begin{array}{c}0.061 \\
(0.124)\end{array}$ & & & \\
\hline GOV_ADMIN $(-1)^{*}$ crisis & & & & & $\begin{array}{c}0.113 \\
(0.129)\end{array}$ & & & \\
\hline INTERVENTION (-1)*pre-crisis & $\begin{array}{c}-0.210^{* * * *} \\
(0.028)\end{array}$ & & $\begin{array}{c}-0.206^{* * *} \\
(0.028)\end{array}$ & & $\begin{array}{c}-0.152 * * * \\
(0.029)\end{array}$ & & & \\
\hline INTERVENTION (-1)*crisis & $\begin{array}{c}-0.248 * * * \\
(0.028)\end{array}$ & & $\begin{array}{c}-0.173 * * * \\
(0.028)\end{array}$ & & $\begin{array}{c}-0.260 * * * \\
(0.028)\end{array}$ & $* * *$ & & \\
\hline NO_INTERV $(-1)^{*}$ pre-crisis & & & & & & & $\begin{array}{l}-0.192 * \\
(0.107)\end{array}$ & \\
\hline NO_INTERV $(-1) *$ crisis & & & & & & & $\begin{array}{l}-0.245^{* *} \\
(0.117)\end{array}$ & \\
\hline NO_CANCEL $(-1)$ *pre-crisis & & & & & & & $\begin{array}{c}-0.264 * * * \\
(0.045)\end{array}$ & \\
\hline NO_CANCEL $(-1) *$ crisis & & & & & & & $\begin{array}{c}-0.374 * * * \\
(0.032)\end{array}$ & $* *$ \\
\hline NO_LEGALPWR (-1)*pre-crisis & & & & & & & $\begin{array}{c}-0.116^{* * *} \\
(0.034)\end{array}$ & \\
\hline NO_LEGALPWR (-1)*crisis & & & & & & & $\begin{array}{c}0.081 \\
(0.061)\end{array}$ & **** \\
\hline Control_var (-1) & Yes & & Yes & & Yes & & Yes & \\
\hline CRISIS & $\begin{array}{c}0.023 \\
(0.098)\end{array}$ & & $\begin{array}{c}-0.236 * * \\
(0.099)\end{array}$ & & $\begin{array}{c}0.109 \\
(0.099)\end{array}$ & & $\begin{array}{l}-0.218 \\
(0.150)\end{array}$ & \\
\hline Bank FE & Yes & & Yes & & Yes & & Yes & \\
\hline Cluster SE Bank & Yes & & Yes & & Yes & & Yes & \\
\hline N. of obs. & 27,584 & & 27,584 & & 27,584 & & 27,584 & \\
\hline R-squared & 0.055 & & 0.062 & & 0.062 & & 0.058 & \\
\hline
\end{tabular}


Table 7 - Panel estimation results with blanket guarantee

This table reports estimates of bank fixed-effect (FE) regressions over the period 2008-2010. The dependent variable is the natural logarithm of the Z-score. The variables of interest are: BLANKET, FUNDING \& ADMIN, and INTERVENTION. The control variables include: SIZE, ETA, DEP_TA, CIR, DIV, LLR_GL, HHI, $\triangle$ GDP, and GDP_PC. Variable definitions are provided in Table 1. Independent variables are lagged by one year with respect to the dependent variable. All non-binary variables are winsorized at the $1 \%$ of each tail. Bank clustered standard errors (SE) are reported in parentheses. The superscripts $* * *, * *$, and $*$ denote coefficients statistically different from zero at the $1 \%, 5 \%$, and $10 \%$ levels, respectively, in two-tailed tests.

\begin{tabular}{|c|c|}
\hline Variables & Z-score \\
\hline BLANKET (-1) & $\begin{array}{c}0.205 * * * \\
(0.046)\end{array}$ \\
\hline FUNDING \& ADMIN (-1) & $\begin{array}{c}0.023 \\
(0.059)\end{array}$ \\
\hline INTERVENTION (-1) & $\begin{array}{c}-0.107 * * * \\
(0.043)\end{array}$ \\
\hline Control_var (-1) & Yes \\
\hline Bank FE & Yes \\
\hline Cluster SE Bank & Yes \\
\hline N. of obs. & 9,356 \\
\hline R-squared & 0.023 \\
\hline
\end{tabular}


Table 8 - Estimates with the magnitude of regulatory changes in deposit coverage throughout 20082013

This table reports estimates of OLS regressions during the period 2008-2013. The dependent variable is the natural logarithm of the Z-score. The variables of interest in model are: AFFECTED, HIGH_COV07, their interaction term (AFFECTED*HIGH_COV07), NO_COINS, FUNDING \& ADMIN, and INTERVENTION. The variable AFFECTED is a dummy variable that takes value 1 for those banks located in countries which experienced a change in coverage equals or above the mean of all changes occurred within 2010, and 0 otherwise. The variable HIGH_COV07 is a dummy that takes the values of the already defined HIGH_COV07. These two variables and their interaction are not lagged. The control variables include: SIZE, ETA, DEP_TA, CIR, DIV, LLR_GL, HHI, $\triangle$ GDP, and GDP_PC. Definitions of the remaining variables are provided in Table 1 . NO_COINS, FUNDING \& ADMIN, INTERVENTION and the control variables are lagged by one year with respect to the dependent variable. All non-binary variables are winsorized at the $1 \%$ of each tail. Bank clustered standard errors (SE) are reported in parentheses. The superscripts ***,**, and * denote coefficients statistically different from zero at the $1 \%, 5 \%$, and $10 \%$ levels, respectively, in two-tailed tests.

\begin{tabular}{lc}
\hline Variables & Z-score \\
\hline AFFECTED & $0.814^{* * *}$ \\
HIGH_COV07 & $(0.179)$ \\
& $3.531^{* * *}$ \\
AFFECTED*HIGH_COV07 & $(0.674)$ \\
& $-2.149^{* * *}$ \\
NO_COINS (-1) & $(0.444)$ \\
FUNDING \& ADMIN (-1) & $-0.083^{* *}$ \\
& $(0.042)$ \\
INTERVENTION (-1) & $0.632^{* * *}$ \\
Control_var (-1) & $(0.055)$ \\
Country FE & $-0.209 * * *$ \\
Year FE & $(0.037)$ \\
Cluster SE Bank & Yes \\
N. of obs. & Yes \\
R-squared & Yes \\
\hline
\end{tabular}


Table 9 - Sources of bank stability: Z-score proxies

This table reports estimates of bank fixed-effect (FE) regressions for the full sample over the period 2003-2013 using the components of the Z-score (equity to total assets - ETA; return on average assets - ROAA; and three-year standard deviation of ROAA - $\sigma$ ROAA), the quality of the loan portfolio and the Tier 1 capital ratio as dependent variables. The variables of interests are: COVERAGE, FUNDING \& ADMIN, and INTERVENTION. All our target variables are interacted with the pre-crisis (2003-2007) and crisis years (20082013), respectively. The control variables include: SIZE, ETA, DEP_TA, CIR, DIV, LLR_GL, HHI, $\triangle$ GDP, and GPDPC. When we use ETA and LLR_GL as dependent variable, we obviously exclude them from the control variables. Variable definitions are provided in Table 1. Independent variables are lagged by one year with respect to the dependent variable. All non-binary variables are winsorized at the $1 \%$ of each tail. Bank clustered standard errors are reported in parentheses. The superscripts $* * *, * *$, and $*$ denote coefficients statistically different from zero at the $1 \%, 5 \%$, and $10 \%$ levels, respectively, in two-tailed tests.

\begin{tabular}{|c|c|c|c|c|c|}
\hline Variables & ETA & ROAA & oROAA & LLR_GL & TIER1 RATIO \\
\hline \multirow[t]{2}{*}{ COV_RATIO (-1)*pre-crisis } & $0.013 * * *$ & $0.003 * * *$ & -0.021 & $-0.004 * * *$ & $1.964 * *$ \\
\hline & $(0.003)$ & $(0.000)$ & $(0.030)$ & $(0.001)$ & $(0.855)$ \\
\hline \multirow[t]{2}{*}{ COV_RATIO2 (-1)*pre-crisis } & -0.002 & $-0.002 * * *$ & 0.026 & $0.006^{* * * *}$ & 0.000 \\
\hline & $(0.003)$ & $(0.000)$ & $(0.027)$ & $(0.001)$ & $(0.696)$ \\
\hline \multirow[t]{2}{*}{ COV_RATIO $(-1) *$ crisis } & $0.008 * * *$ & $0.001 * * *$ & $-0.067 * * *$ & $-0.001 * *$ & $1.398 * * *$ \\
\hline & $(0.001)$ & $(0.000)$ & $(0.016)$ & $(0.001)$ & $(0.226)$ \\
\hline \multirow[t]{2}{*}{ COV_RATIO2 $(-1) *$ crisis } & $0.002 *$ & $-0.001 * * *$ & $0.082 * * *$ & $0.008 * * *$ & 0.011 \\
\hline & $(0.001)$ & $(0.000)$ & $(0.019)$ & $(0.001)$ & $(0.163)$ \\
\hline \multirow[t]{2}{*}{ FUNDING \& ADMIN (-1)*pre-crisis } & 0.001 & 0.001 & -0.005 & -0.001 & $1.361^{* *}$ \\
\hline & $(0.002)$ & $(0.000)$ & $(0.038)$ & $(0.001)$ & $(0.666)$ \\
\hline \multirow[t]{2}{*}{ FUNDING \& ADMIN $(-1)^{*}$ crisis } & 0.000 & $-0.001 * * *$ & $0.085^{* *}$ & 0.001 & $1.271^{*}$ \\
\hline & $(0.002)$ & $(0.001)$ & $(0.039)$ & $(0.001)$ & $(0.663)$ \\
\hline \multirow[t]{2}{*}{ INTERVENTION (-1)*pre-crisis } & $0.005 * * *$ & $-0.001 * * *$ & $0.071 * * *$ & $0.001 * * *$ & -0.356 \\
\hline & $(0.001)$ & $(0.000)$ & $(0.011)$ & $(0.000)$ & $(0.428)$ \\
\hline \multirow[t]{2}{*}{ INTERVENTION $(-1) *$ crisis } & $-0.004 * * *$ & $-0.001 * * *$ & -0.013 & $0.001^{* *}$ & 0.039 \\
\hline & $(0.001)$ & $(0.000)$ & $(0.013)$ & $(0.001)$ & $(0.295)$ \\
\hline Control_var (-1) & Yes & Yes & Yes & Yes & Yes \\
\hline \multirow{2}{*}{ CRISIS } & $0.022 * * *$ & -0.001 & $0.155^{* * * *}$ & -0.001 & 0.051 \\
\hline & $(0.003)$ & $(0.001)$ & $(0.048)$ & $(0.002)$ & (1.244) \\
\hline Bank FE & Yes & Yes & Yes & Yes & Yes \\
\hline Cluster SE Bank & Yes & Yes & Yes & Yes & Yes \\
\hline N. of obs. & 27,584 & 27,584 & 27,584 & 27,556 & 10,413 \\
\hline R-squared & 0.111 & 0.163 & 0.074 & 0.183 & 0.095 \\
\hline
\end{tabular}


Table 10 - Exogeneity of deposit insurance coverage increase and blanket guarantees

The table reports a Cox (1972) proportional hazard (Cox PH) model to verify that the increase of deposit insurance coverage above average over the period 2008-2010, proxied by the treatment variable AFFECTED, and the introduction of a blanket guarantee (BLANKET) are exogenous with respect to bank stability, measured by the natural logarithm of the Z-score. The independent variable denotes the hazard of observing above average deposit insurance coverage increase and blanket guarantees. Our sample period is 2003-2010. A country is released from the analysis once it experiences the intervention of interest. The control variables include: SIZE, ETA, DEP_TA, CIR, DIV, LLR_GL, HHI, $\triangle$ GDP, and GDP_PC. Definitions of the remaining variables are provided in Table 1. Standard errors are robust. Robust t-statistics are given in parentheses. $*$, **, and $* * *$ indicate significance at the $1 \%, 5 \%$, and $10 \%$ levels, respectively.

\begin{tabular}{lcc}
\hline Variables & AFFECTED & BLANKET \\
\hline Z-score & 0.718 & 0.805 \\
& $(0.109)$ & $(0.296)$ \\
Control_var & Yes & Yes \\
N. of obs. & 188 & 188 \\
\hline
\end{tabular}


Figure 1 - The relationship between bank stability and deposit coverage

The figure gives qualitative evidence of the non-linear relation between banks' stability (measured by the natural logarithm of the Z-score) and the coverage ratio - COV_RATIO (measured by the natural logarithm of the ratio of deposit insurance on the real GDP per capita), before and during the crisis.
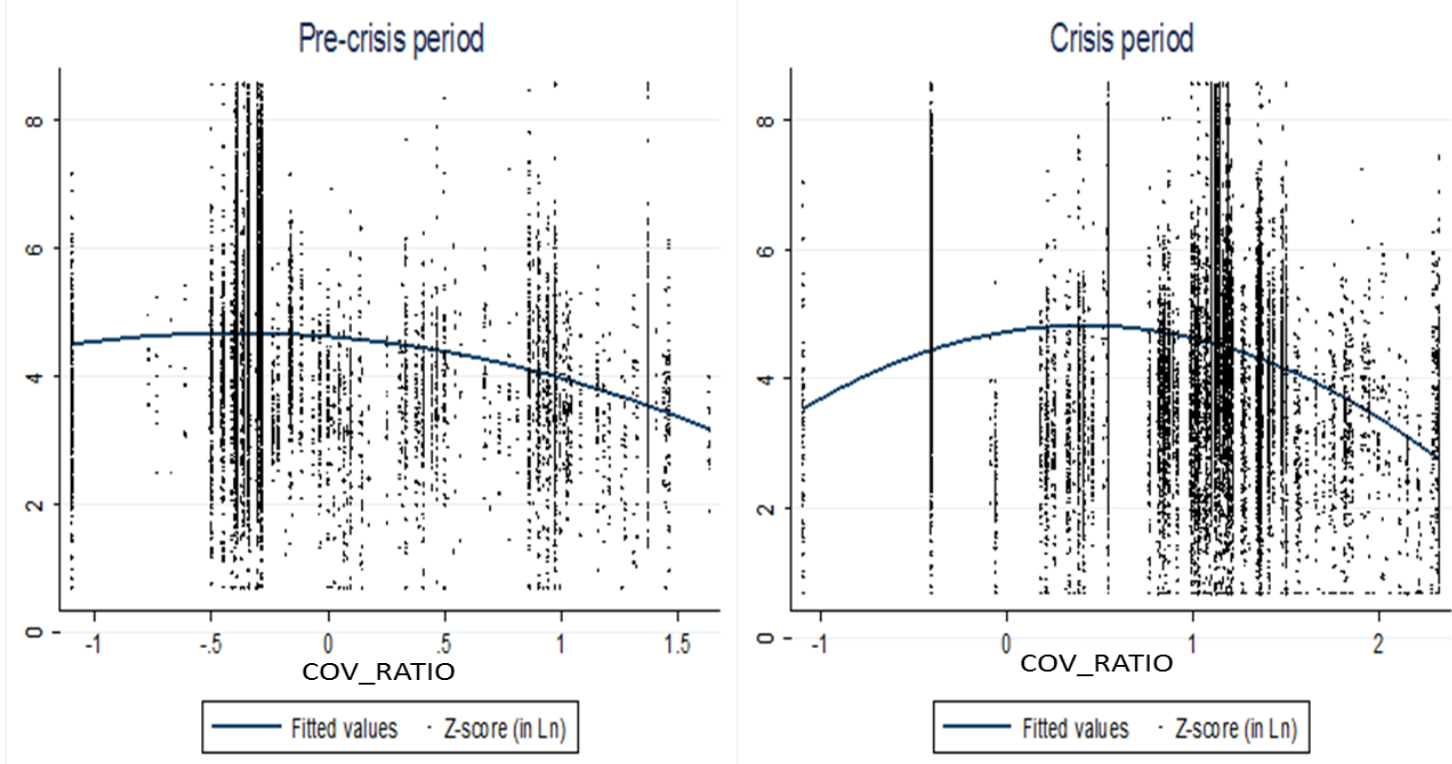


\section{Appendix}

Table A.1 - Correlation Matrix

This table shows the correlation matrix of the variables used in the empirical analysis over the period 2003-2013. Variable definitions are provided in Table 1 . The symbol * indicates statistically significance at the $5 \%$ level.

\begin{tabular}{|c|c|c|c|c|c|c|c|c|c|c|c|c|c|}
\hline Variables & Z-score & COVERAGE & FUNDING \& ADMIN & INTERVENTION & SIZE & ETA & DEP_TA & CIR & DIV & LLR_GL & $\mathrm{HHI}$ & $\Delta \mathrm{GDP}$ & GDP_PC \\
\hline Z-score & 1 & & & & & & & & & & & & \\
\hline COVERAGE & $-0.2907 *$ & 1 & & & & & & & & & & & \\
\hline FUNDING \& ADMIN & $-0.3061 *$ & $0.3273^{*}$ & 1 & & & & & & & & & & \\
\hline INTERVENTION & $-0.0934 *$ & $-0.0399 *$ & $0.0502 *$ & 1 & & & & & & & & & \\
\hline SIZE & $-0.0674 *$ & $0.1174 *$ & $0.1495^{*}$ & $-0.1598 *$ & 1 & & & & & & & & \\
\hline ETA & $-0.0904 *$ & $0.2087^{*}$ & $0.1596^{*}$ & $0.0427 *$ & $-0.2960 *$ & 1 & & & & & & & \\
\hline DEP_TA & $0.2091 *$ & $-0.3246 *$ & $-0.1657 *$ & $-0.0297 *$ & $-0.3112 *$ & $-0.2887 *$ & 1 & & & & & & \\
\hline $\mathrm{CIR}^{-}$ & $-0.0715^{*}$ & $-0.0647^{*}$ & $-0.1146 *$ & $0.0431 *$ & $-0.2238 *$ & 0.0072 & $0.1298^{*}$ & 1 & & & & & \\
\hline DIV & $-0.1824 *$ & $0.0553^{*}$ & $0.0712^{*}$ & $-0.0383^{*}$ & $0.1259^{*}$ & $0.1467 *$ & $-0.1610^{*}$ & $0.1046^{*}$ & 1 & & & & \\
\hline LLR_GL & $-0.2827 *$ & $0.4326^{*}$ & $0.1902 *$ & $0.0742 *$ & $0.1508 *$ & $0.1104 *$ & $-0.1948 *$ & -0.0005 & $0.0553 *$ & 1 & & & \\
\hline $\mathrm{HHI}$ & $-0.3340 *$ & $0.2920^{*}$ & $0.3588^{*}$ & $-0.0092^{*}$ & $0.1603^{*}$ & $0.1347^{*}$ & $-0.1341 *$ & $-0.0460 *$ & $0.0960 *$ & $0.2562^{*}$ & 1 & & \\
\hline$\Delta \mathrm{GDP}$ & $0.0591 *$ & $-0.2035^{*}$ & $0.0917 *$ & $0.0310^{*}$ & $-0.0169 *$ & -0.0034 & $0.0698^{*}$ & $-0.0452 *$ & $0.0641 *$ & $-0.1354 *$ & $0.0683^{*}$ & 1 & \\
\hline GDP_PC & $0.1460 *$ & $-0.2328 *$ & $-0.1410^{*}$ & $-0.1538^{*}$ & $-0.0207 *$ & $-0.0624 *$ & $0.0890 *$ & $-0.0384 *$ & 0.0026 & $-0.2539 *$ & $-0.2159^{*}$ & $-0.1105^{*}$ & 1 \\
\hline
\end{tabular}

